\title{
King v. Burwell and the Chevron Doctrine: Did the Court Invite Judicial Activism?
}

\author{
Matthew A. Melone*
}

Judges are too often inclined to fold their hands and blame the legislature, when they really ought to set to work to give the words a reasonable meaning, even if this does involve a departure from the letter of them. By so acting they are more likely to find the truth.

Lord Denning¥

President Barack Obama signed into law the Patient Protection and Affordable Care $\mathrm{Act}^{1}$ on March 23, 2010. The legislation, arguably President Obama's signature achievement, enacted sweeping changes to the health care industry. The Act, among its many provisions, mandates health insurance coverage, expands Medicaid, establishes insurance exchanges, enacts changes to Medicare, introduces preventive health programs, and subjects individuals and employers to a number of penalties, taxes, and other assessments. ${ }^{2}$ The legislation has generated significant controversy in the past five years. The Supreme Court, in a trilogy of highly publicized cases, upheld a significant part of the Act in the face of a constitutional challenge but also struck down certain provisions on both constitutional and statutory grounds.

In 2012, the Court upheld what was perhaps the most contentious provision in the legislation - the so-called individual mandate, which is the requirement that individuals obtain health insurance coverage or face

* J.D., University of Pennsylvania; C.P.A.; Professor of Law, Lehigh University, Bethlehem, PA $¥$ The Rt. Hon. Lord Edmund-Davies, Lord Denning: Christian Advocate and Judge, 1 DENNING L. J. 41, 43 (1986) (quoting Lord Denning).

1. Pub. L. No. 111-148, 124 Stat. 119 (2010).

2. See Florida v. U.S. Dep't of Health \& Human Servs., 648 F.3d 1235, 1248-49 (11th Cir. 2011) (discussing the legislation's scope); see also TREASURY INSPECTOR GEN. FOR TAX ADMIN., Affordable Care Act: Planning EfForts for the TaX Provisions of the Patient Protection and AfFordable Care Act ApPear Adequate; However, the Resource ESTIMATION PROCESS NEEDS IMPROVEMENT, Highlights (2012), https://www.treasury.gov/tigta/auditreports/2012reports/201243064fr.pdf (noting that the legislation "includes the largest set of tax law changes in more than 20 years"). 
financial penalties. ${ }^{3}$ In that same case, the Court struck down, on federalism grounds, the parts of the legislation that expanded Medicaid coverage. ${ }^{4}$ In 2014, the Court held that, pursuant to the Religious Freedom Restoration Act, the requirement to provide certain contraceptive coverage could not be enforced against three closely-held corporations. ${ }^{5}$

In the final case of the trilogy, the issue before the Court was whether tax credits are available to qualified individuals who purchase health insurance on either Federal or State Exchanges or whether such credits are limited to qualified individuals who purchase health insurance on State Exchanges. ${ }^{6}$ The tax credits subsidize the cost of health insurance for lower income individuals and are critical to the achievement of near universal health coverage. ${ }^{7}$ Moreover, this subsidy is also important in the prevention of the phenomenon of adverse selection and the attendant chaos that this phenomenon may create in the health insurance market. ${ }^{8}$ This issue took on heightened importance because Federal Exchanges serve consumers in a vast majority of states. ${ }^{9}$ On June 25, 2015, the Court held that the Act makes available tax credits to qualified individuals who purchase health insurance on Federal Exchanges. ${ }^{10}$

The Court's decision was an interesting exercise in statutory construction. Frankly, the arguments set forth by both the majority and dissenting opinions were convincing. However, the manner in which the Court handled the issue of judicial deference to the Internal Revenue Service (I.R.S.) regulations in question was troubling. The Court did not defer to the I.R.S. despite the admitted ambiguity of the statute because the issue presented was extraordinary and, as such, belied the congressional intent to delegate its resolution to the I.R.S. ${ }^{11}$ The Court also questioned the expertise of the agency with respect to health care

3. Nat'l Fed'n of Indep. Bus. v. Sebelius, 132 S. Ct. 2566, 2608 (2012). See infra note 23 and accompanying text.

4. Nat'l Fed'n of Indep. Bus., 132 S. Ct. at 2607. See infra note 44 (explaining the part of the legislation that expanded Medicaid coverage).

5. Burwell v. Hobby Lobby Stores, Inc., 134 S. Ct. 2751, 2785 (2014). See infra note 41.

6. King v. Burwell, 135 S. Ct. 2480, 2487 (2015).

7. See infra notes $42-53$ and accompanying text.

8. See infra notes $21,105,110$ and accompanying text.

9. See infra note 19 and accompanying text.

10. King, 135 S. Ct. at 2496. See infra notes 107-69 and accompanying text.

11. See infra notes $118-19$ and accompanying text. 
policy. ${ }^{12}$ However, the Court's methodology appears to provide the judicial branch with the opportunity to impose its own policy preferences with respect to issues best left to Congress.

Part I of this Article provides an overview of the Patient Protection and Affordable Care Act. It includes a discussion of the Exchanges, the individual and employer mandates, and the tax credit. Part II provides an analysis of the two cases that created a Circuit Court split with respect to the issue of tax credit availability and the Supreme Court decision. Part III critiques the Court's deference jurisprudence and asserts that the Court's reasoning can be taken as an invitation to judicial policy-making. This part also includes two examples of recent issues to illustrate how ambiguities in extraordinary cases could, conceivably, be resolved by the courts despite the fact that Congress did not see fit to delegate the issue to another body. This part also asserts that the Court's standing jurisprudence is fundamentally at odds with its deference jurisprudence in the extraordinary cases in which deference to an agency is unwarranted.

\section{PATIENT PROTECTION AND AFFORDABLE CARE ACT: AN OVERVIEW}

\section{A. The Exchanges}

The Patient Protection and Affordable Care Act segments the health insurance market into four markets: the individual market, two employerprovided group insurance markets, the small and large group market, and the American Health Benefit Exchanges (Exchanges). ${ }^{13}$ The Exchanges are governmental or non-profit entities that, inter alia, establish, and monitor compliance with, insurance standards and function as insurance marketplaces in which individuals have the ability to comparison-shop for insurance products. ${ }^{14}$ Each state must create and operate, as of January 1, 2014, an Exchange that offers insurance for purchase by individuals and employees of small employers. ${ }^{15}$ Under certain

12. See infra notes 119-20 and accompanying text.

13. Patient Protection and Affordable Care Act, Pub. L. No. 111-148, §§ 1304, 1311, 1312 , 124 Stat. 119, 171, 174, 182 (2010) (codified at 42 U.S.C. $\$ \S 18024,18031,18032$ (2012)). The federal government provided funding to states to establish the Exchanges until January 1, 2015. Id. $\S 1311(\mathrm{~d})(5)(\mathrm{A}), 124$ Stat. at 178 (codified at 42 U.S.C. $\S 18031$ (2012)).

14. Id. $\S 1311,124$ Stat. at 173 (codified at 42 U.S.C. $\$ 18031(\mathrm{~d})(1)-(4)(2012)$ ).

15. Id. $\S 1311(\mathrm{~b}), 124$ Stat. at 173 (codified at 42 U.S.C. $\S 18031$ (2012)). After 2016, states have the option of allowing large employers to participate in the Exchanges. Id. $§ 1312(\mathrm{f})(2)(\mathrm{B})$, 
circumstances, a state may participate in a multi-state regional Exchange or establish subsidiary Exchanges to operate within a state. ${ }^{16}$ A state may opt out of creating and operating an Exchange in which case the Exchange will be established by the federal government. ${ }^{17}$ These Exchanges may be operated exclusively by the Department of Health and Human Services or in partnership with the state with authority over the operation of the Exchange residing within the Department of Health and Human Services. ${ }^{18}$ Fifteen states and the District of Columbia have established Exchanges. ${ }^{19}$

\section{B. Mandates}

The Patient Protection and Affordable Care Act added section 5000A to the Internal Revenue Code-the so-called individual mandate. ${ }^{20}$ The

124 Stat. at 184 (codified at 42 U.S.C. $§ 18032$ (2012)). Qualified employers may also purchase group plans through the Exchanges. Id. § 1311(d)(2), 124 Stat. at 176 (codified at 42 U.S.C. $\S$ 18031 (2012)). Small employers purchasing coverage for their employees through the Exchanges may be eligible for a tax credit up to 50 percent of the cost of their contributions toward such coverage. The credit phases out based on the number of individuals employed full-time by the employer and the average wages paid by the employer. No credit is allowed for employers with 25 or more full-time employees or employers that pay average wages in excess of $\$ 50,000$, adjusted for inflation after 2013. See I.R.C. $\S 45 R$ (West 2015). Small business utilization of the Exchanges has been tepid, in part due to minimal insurance options available on the Exchanges and, in part, due to the often-meager tax credit available. See Adam Janofsky, Small Businesses Spurn Health Exchange, WALL ST. J., Jan. 8, 2015, at B4.

16. Patient Protection and Affordable Care Act $\S 1311$ (f), 124 Stat. at 179 (codified at 42 U.S.C. $\$ 18031$ (2012)). See also 45 C.F.R. § 155.140 (2013).

17. Patient Protection and Affordable Care Act $\S 1321(c), 124$ Stat. at 186 (codified at 42 U.S.C. $\S 18041$ (2012)).

18. See Bernadette Fernandez \& Annie L. Mach, Health Insurance Exchanges Under the Patient Protection and Affordable Care Act (ACA), CONG. RES. SERV. 12-13 (Jan. 31, 2013), https://www.fas.org/sgp/crs/misc/R42663.pdf. Seven Exchanges operate under this model; see also State Health Insurance Marketplace Types, 2016, THE HENRY J. KAISER FAMILY Found., http://kff.org/health-reform/state-indicator/state-health-insurance-marketplace-types/ (last visited Jan. 6, 2016). Four states operate federally supported Exchanges. Id. These Exchanges are operated by state authorities through the use of federal information technology infrastructure. Id.

19. See State Health Insurance Exchange: State Run Exchanges, OBAmACARE FACTS, http://obamacarefacts.com/state-health-insurance-exchange/ (last visited Jan. 6, 2016). Residents of other states purchase health insurance through a Federal Exchange using the HealthCare.Gov portal. During the 2015 open enrollment period, approximately 8.8 million individuals obtained coverage on federally-assisted Exchanges. Robert Pear, 86 Percent of Health Law Enrollees Receive Subsidies, White House Says, N.Y. TIMES, March 11, 2015, at A17. During the original enrollment period between October 1, 2013 and March 31, 2014, approximately 5.4 million individuals were enrolled on the Federal Exchanges. Amy Burke et al., Premium Affordability, Competition, and Choice in the Health Insurance Marketplace, DePT. OF HEAlth \& HumAn SERVS. (June 18, 2014), https://aspe.hhs.gov/sites/default/files/pdf/76896/2014MktPlacePremBrf.pdf.

20. Patient Protection and Affordable Care Act $\S \$ 1501$ (b), 10106(b)(1), 124 Stat. at 244-49, 909-10 (codified as amended at I.R.C. § 5000A (2012)). The penalty amount imposed by the statute 
individual mandate is critical to the mitigation of adverse selection in light of the insurance market reforms that were part of the legislation. ${ }^{21}$ This provision survived a constitutional challenge when the Court, in National Federation of Independent Business v. Sebelius, upheld it under Congress's taxing power despite holding that its enactment exceeded Congress's power to regulate interstate commerce. ${ }^{22}$ The individual mandate requires that an applicable individual maintain minimum essential coverage for such individual and any dependents that are also applicable individuals each month beginning after $2013 .^{23}$ Failure to maintain such coverage for one or more months results in the imposition of a shared responsibility payment - a penalty that is to be included with a taxpayer's income tax return for the taxable year, which includes the month that such failure occurred. ${ }^{24}$ The requirement to maintain

was amended shortly thereafter by the Health Care and Education Reconciliation Act of 2010, Pub. L. No. 111-152, § 1002, 124 Stat. 1029, 1032-33 (2010) (codified at I.R.C. § 5000A (2012)).

21. Adverse selection refers to the propensity of those most in need of insurance to purchase it while those individuals with little or no perceived need of insurance - the young and healthy, for example-forego its purchase. Adverse selection reduces the number of no or low claim customers needed by the insurers to keep premiums affordable. Among the insurance market reforms are community rating and guarantee issue requirements. Insurers may not price discriminate on any basis except age, family size, smoking, and geographic areas. Consequently, insurers can neither deny coverage to those individuals with pre-existing medical conditions nor price their coverage to account for such pre-existing conditions. See Patient Protection and Affordable Care Act $\S 1201$, 124 Stat. at 155 (codified at 42 U.S.C. $\S \S 300 \mathrm{gg}-1,300 \mathrm{gg}-3$ (2012)). For a succinct discussion of the changes the Act made to the health insurance market see Sarah Somers \& Jane Perkins, The Affordable Care Act: A Giant Step Toward Insurance Coverage for All Americans, 44 ClEARINGHOUSE REV.

330

http://povertylaw.org/system/files/chr_article_pdf/chr_2010_november_december_somers.pdf. See also Jonathan Gruber, The Impacts of the Affordable Care Act: How Reasonable are the Projections? 4-7 (Nat'l Bur. of Econ. Research, Working Paper No. 17168, 2011). Whether or not the legislative scheme works as intended remains to be seen but there is evidence that the adverse selection is alive and well in some markets. See Abby Goodnough, Success of Kentucky's Health Plan Comes With New Obstacles, N.Y. TIMES, Dec. 30, 2014, at A1.

22. 132 S. Ct. 2566, 2593, 2600 (2012).

23. I.R.C. $\S 5000 \mathrm{~A}(\mathrm{a})$. The term "applicable individual" excludes individuals who qualify for statutorily defined religious conscience or health ministry exemptions, who are not citizens or nationals of the United States or legal aliens present in the United States, or who are incarcerated. $I d$. $\S 5000 \mathrm{~A}(\mathrm{~d})$. Individuals whose required contribution exceeds eight percent of household income, individuals with very low income, and members of Indian tribes are not subject to the penalty. $I d$. $\S$ $5000 \mathrm{~A}(\mathrm{e})(1)-(3)$.

24. Id. $\S 5000 \mathrm{~A}(\mathrm{~b})(1)-(2)$. Recent government estimates anticipate that approximately six million households may be subject to the individual mandate for 2014. See Stephanie Armour, Millions Face a Health-Insurance Penalty, WALL ST. J., Jan. 29, 2015, at A3. No penalty is imposed for gaps in coverage of less than three months. I.R.C. $\$ 5000 \mathrm{~A}(\mathrm{e})(4)$. The penalty is assessed and collected in the same manner as other assessable penalties but neither criminal penalties may be imposed nor criminal prosecution undertaken for failure to pay the penalty. Moreover, liens and levies to collect unpaid penalties are prohibited. $I d$. $5000 \mathrm{~A}(\mathrm{~g})$. 
minimum essential coverage is variously met through, among other means, Medicare or Medicaid coverage, individual insurance policies, or eligible employer-sponsored group health plans or insurance coverage. ${ }^{25}$

An applicable individual is an individual other than an individual who qualifies for statutorily defined religious conscience or health ministry exemptions, who is not a citizen or national of the United States or a legal alien present in the United States, or who is incarcerated. ${ }^{26}$ No penalty is imposed on individuals whose required contribution exceeds eight percent of household income. ${ }^{27}$ The required contribution for individuals who are eligible only to purchase insurance in the individual market is the annual premium for the lowest bronze plan available in the market in which the individual resides reduced by the amount of any credit available under section $36 \mathrm{~B}^{28}$ The tax credit, discussed subsequently, reduces the amount of a taxpayer's required contribution and thus potentially reducing the number of taxpayers who would be entitled to this exemption. ${ }^{29}$ Finally, individuals with very low incomes, members of Indian tribes, and bona-fide residents of any possession of the United States are not subject to the penalty. ${ }^{30}$

The amount of the penalty due for a taxable year is the lesser of the sum of the monthly penalty amounts or the amount of the national average insurance premiums for a particular level of coverage for the applicable family size involved that is offered through insurance Exchanges. ${ }^{31}$ The monthly penalty amount is one-twelfth of the greater

25. Id. $\S 5000 \mathrm{~A}(\mathrm{f})$. Policies whose medical coverage is secondary to the primary purpose of the policy, such as auto insurance policies, credit insurance policies, and workers' compensation coverage are not deemed to provide minimum essential coverage. Also, minimum essential coverage is not provided by policies whose coverage is limited to medical treatment received at onsite medical clinics or for specific illnesses or diseases. See id. §5000A(f)(3); 42 U.S.C. § 300gg91(c) (2012).

26. I.R.C. $\S 5000 \mathrm{~A}(\mathrm{~d})(2012)$.

27. Id. $\S 5000 \mathrm{~A}(\mathrm{e})(1)(\mathrm{A})$.

28. Id. $\S 5000 \mathrm{~A}(\mathrm{e})(1)(\mathrm{B})(\mathrm{ii})$. Bronze level coverage is designed to provide benefits that are actuarially equivalent to 60 percent of the full actuarial value of statutorily enumerated benefits. 42 U.S.C. $\S \S 18022$ (b),(d) (2012). Silver, gold, and platinum coverage levels provide benefits that are actuarially equivalent to 70,80 , and 90 percent of the full actuarial value of statutorily enumerated benefits, respectively. Id. $\$ 18022$ (d). See infra notes 42-53 and accompanying text for a discussion of the tax credit allowable under I.R.C. $\S 36 \mathrm{~B}$. The required contribution for an individual eligible for coverage under an eligible-employer sponsored plan is the annual premium that would be paid by the individual for self-coverage. $I d$. $\$ 5000 \mathrm{~A}(\mathrm{e})(1)(\mathrm{B})(\mathrm{i})$.

29. See infra notes $47-48$ and accompanying text.

30. I.R.C. $\S \S 5000 \mathrm{~A}(\mathrm{e})(2)-(3),(\mathrm{f})(4)(\mathrm{B})$. Bona-fide residents of possessions of the United States are deemed to have minimum essential coverage and, therefore, are not subject to the penalty. See id. $\$ 5000 \mathrm{~A}(\mathrm{f})(4)(\mathrm{B})$.

31. Id. $\S 5000 \mathrm{~A}(\mathrm{c})(1)$. The national average premium is determined for plans that provide a 
of a flat dollar amount or a percentage of income. ${ }^{32}$

A significant portion of health insurance is delivered to individuals through their employers. This system, aided and abetted by income tax subsidies, had its genesis as a mechanism to avoid wage controls during World War II. ${ }^{33}$ The addition of section $4980 \mathrm{H}$ to the Internal Revenue Code by the Patient Protection and Affordable Care Act was made to prevent employers, given the tax credits and subsidies discussed subsequently, from dropping health insurance coverage for their employees and dumping their employees on the Exchanges. ${ }^{34}$ This

bronze level of coverage. See supra note 28 . The monthly national average bronze plan premium for 2015 is $\$ 207$ per individual and $\$ 1,035$ for a family with five or more members. Rev. Proc. 2015-15, 2015-5 I.R.B. 564. The use of the national average premium rather than state average premiums avoids the possibility that the shared responsibility payment violates the uniformity requirement for taxes that are not direct taxes. Congress's power to tax is expansive, but it is not unlimited. In addition to the constitutional limitations applicable to the exercise of any federal power, there are structural limitations specific to the taxing power. Certain taxes must be uniform. U.S. ConST. art. I, $\S 8$, cl.1. The precise contours of the uniformity requirement was subject to some debate during the first century of the republic but it now refers simply to geographic uniformityfederal tax rates must be the same throughout the United States. Knowlton v. Moore, 178 U.S. 41, 83-106 (1900). The uniformity requirement rarely surfaces as a point of contention, perhaps due to the political difficulties that would be encountered in enacting a provision that overtly disfavored a particular geographic region, but on occasion the issue does arise. See, e.g., United States v. Ptasynski, 462 U.S. 74, 86 (1983) (stating that an exemption from an oil profits tax for certain Alaskan oil did not provide Alaska with an undue preference over other states).

32. I.R.C. $\S 5000 \mathrm{~A}(\mathrm{c})(2)$. The flat dollar amount was $\$ 95$ per individual failure in 2014, increased to $\$ 325$ per individual failure in 2015 , and then settles at $\$ 695$ per individual failure thereafter subject to annual cost of living increases beginning in 2017. Id. $\$ \S 5000 \mathrm{~A}(\mathrm{c})(2)(\mathrm{A})$, (c)(3)(A)-(B), (D). The total flat dollar amount penalty cannot exceed 300 percent of the individual amounts. Id. $\S 5000 \mathrm{~A}(\mathrm{c})(2)(\mathrm{A})(\mathrm{ii})$. The tax base for the percentage of income penalty amount is the taxpayer's household income in excess of the amount of gross income that is necessary to impose a duty on the taxpayer to file an income tax return. $I d$. $\S \S 5000 \mathrm{~A}(\mathrm{c})(2)(\mathrm{B}), 6012(\mathrm{a})(1)$. The penalty was equal to one percent of the tax base in 2014, is two percent of the tax base in 2015, and will be two and one-half percent of the tax base thereafter. $I d$. $55000 \mathrm{~A}(\mathrm{c})(2)(\mathrm{B})$.

33. See Thomas C. Buchmueller \& Alan C. Monheit, Employer-Sponsored Health Insurance and the Promise of Health Insurance Reform 3 (Nat'l Bureau of Econ. Research, Working Paper No. 14389, 2009). Although group purchases of insurance yield certain efficiencies, the system has been subject to much criticism by economists because, among other things, it provides greater subsidies to higher income individuals, masks the true cost of coverage to the insured resulting in the overconsumption of medical care, and distorts labor market mobility due to lack of portability. See $i d$. at 8-14. The tax subsidy that results from tax-exempt income is dependent upon the marginal tax rates of the taxpayer who receives such income. The portability issue has been addressed in part by the Consolidated Omnibus Budget Reconciliation Act of 1985 (COBRA), Pub. L. No. 99-272, 100 Stat. 82 (1986). Provisions of this statute mandate that employers with 20 or more full-time equivalent employees offer medical coverage for a period of 18 months to an employee or covered family member after a qualifying event. See generally I.R.C. § 4980B. Among qualifying events are voluntary or involuntary termination of employment, divorce, death, and disability. Id. For certain qualifying events, the coverage period is 29 months or 36 months. Id. The employee must pay for the cost of coverage plus an allowable administrative fee. Id. Failure to provide COBRA coverage subjects an employer to an excise tax. Id.

34. Patient Protection and Affordable Care Act, Pub. L. No. 111-148, §§ 1513, 10106(e), 124 
provision imposes an exaction on certain employers if they either do not offer insurance coverage to their employees or offer coverage that is deemed inadequate under the statute. ${ }^{35}$ An assessable payment is imposed on employers with an average of fifty or more full-time or fulltime equivalent employees during the preceding calendar year if such employers fail to offer affordable minimum essential health care coverage to their full-time employees and one or more such employees qualify for the tax credit or premium subsidies. ${ }^{36}$

The Obama administration has twice delayed the enforcement of these provisions. In 2013, the I.R.S. issued a notice that enforcement of these provisions would be delayed until 2015. ${ }^{37}$ In 2014, final regulations were issued that further delayed enforcement until 2016 for employers with less than 100 full-time equivalent employees or for those

Stat. 119, 253-56, 910-11 (2010) (codified as amended in I.R.C. § 4980H (2012)). See infra notes $42-53$ and accompanying text for a discussion of the tax credits and premium subsidies.

35. I.R.C. $\S 4980 \mathrm{H}$. A federal district court upheld the constitutionality, on Commerce Clause grounds, of both the individual and employer mandates, but its decision was vacated by the Fourth Circuit due to the application of the Anti-Injunction Act. See Liberty Univ., Inc. v. Geithner, 753 F. Supp. 2d 611, 635-36 (W.D. Va. 2010), vacated, Liberty Univ., Inc. v. Geithner, 671 F.3d 391, 403 (4th Cir. 2011), vacated, Liberty Univ., Inc. v. Geithner, 133 S. Ct. 679 (2012), aff'd sub nom., Liberty Univ., Inc. v. Lew, 733 F.3d 72 (4th Cir. 2013). The Anti-Injunction Act prohibits, subject to few exceptions, any "suit for the purpose of restraining the assessment or collection of any tax ... in any court by any person, whether or not such person is the person against whom such tax was assessed.” I.R.C. § 7421(a). However, in National Federation of Independent Business v. Sebelius, the Court held that despite the status of the individual mandate penalty as a tax for constitutional purposes, the penalty was not a tax for purposes of the Anti-Injunction Act. See 132 S. Ct. 2566, 2594 (2012). In light of its holding in National Federation of Independent Business v. Sebelius, the Court granted certiorari and remanded the case back to the Fourth Circuit. Liberty Univ. v. Geithner, 133 S. Ct. 679, 679 (2012). The Fourth Circuit then held that Liberty University had standing to challenge the employer mandate and upheld the constitutionality of the employer mandate. See Liberty Univ., Inc. v. Lew, 733 F.3d 72, 105 (4th Cir. 2013). Both mandates were also challenged in another case. However, the court dismissed the complaint for lack for standing. See N.J. Physicians, Inc. v. Obama, 757 F. Supp. 2d 502, 511 (D.N.J. 2010), aff'd sub nom., N.J. Physicians, Inc. v. President of the United States, 653 F.3d 234 (3d Cir. 2011).

36. I.R.C. $\S \S 4980 \mathrm{H}(\mathrm{a}),(\mathrm{c})(2)(\mathrm{A})$. For this purpose, minimum essential coverage has the same meaning as it has for purposes of the individual mandate imposed by I.R.C. $\S 5000 \mathrm{~A}(\mathrm{f})$. Treas. Reg. $\S 54.4980 \mathrm{H}-1$ (a)(27) (2014). A full-time employee is defined as an employee who is employed an average of at least 30 hours per week. I.R.C. $\S 4980 \mathrm{H}(\mathrm{c})(4)(\mathrm{A})$. Full-time equivalent employees are a combination of employees, none of whom are full-time employees, who are counted as full-time employees for purposes of determining whether an employer is an applicable large employer. Treas. Reg. § 54.4980H-1(a)(22) (2014). The full-time equivalency rules apply only for the purposes of determining whether an employer employs an average of 50 or more full-time employees and not for the purpose of determining the penalty amount. I.R.C. $\S 4980 \mathrm{H}(\mathrm{c})(2)(\mathrm{E})$. Failure to offer such coverage results in the imposition of a penalty for each full-time employee in excess of 30 up to $\$ 2,000$ per annum if no coverage is provided and one employee qualifies for a premium tax credit or cost sharing subsidy. See id. $\S \S 4980 \mathrm{H}(\mathrm{a}), 4980 \mathrm{H}(\mathrm{c})(1),(2)(\mathrm{D})(\mathrm{i})(\mathrm{I})$. The maximum annual penalty amount is $\$ 3,000$ if unaffordable coverage is offered. See I.R.C. $\$ 4980 \mathrm{H}(\mathrm{b})(1)$.

37. I.R.S. Notice 2013-45, 2013-31 I.R.B. 116. 
employers with 100 or more full-time equivalent employees that provide affordable health insurance coverage to at least 70 percent of employees. ${ }^{38}$ The delays have generated controversy because the statute does not authorize such delays. ${ }^{39}$

In addition, an excise tax is imposed in the amount of $\$ 100$ per day for each affected individual if the group health plan does not conform to the requirements of the Patient Protection and Affordable Care Act. ${ }^{40}$ The application of both section $4980 \mathrm{H}$ and the excise tax were at issue in the Court's recent holding that closely-held corporations are protected by the Religious Freedom Restoration Act. ${ }^{41}$

38. Shared Responsibility for Employers Regarding Health Coverage, 79 Fed. Reg. 8544, 8574-75 (Feb. 12, 2014) (to be codified at 26 C.F.R. pts. 1, 54, \& 301). Moreover, employers with 100 or more full-time equivalent employees will not be subject to the full mandate in 2016 if they provide coverage to at least 95 percent of employees. Treas. Reg. $\$ 54.4980 \mathrm{H}-4$ (2014). The final rules prohibit the application of these transition rules if the employer reduces the size of its workforce or the overall hours of service of its employees between February 9, 2014, and December 31,2014 , in order to qualify for relief under the less than 100 full-time equivalent employee test. Shared Responsibility for Employers Regarding Health Coverage, 79 Fed. Reg. at 8574. Workforce or hour reductions are permitted for bona fide business reasons. Id. Moreover, transition relief is denied to employers that would otherwise qualify if such employer eliminates or materially reduces health coverage it offered as of February 9, 2014. Id. Employers subject to the mandate for plan years beginning in 2015 will be subject to an assessable payment only for full-time employees in excess of 80 instead of full-time employees in excess of 30 as previously noted. Id. at 8575 .

39. The House of Representatives has filed a lawsuit over the administration's actions. See Complaint, U.S. House of Representatives v. Burwell, No. 14-1967, 2015 WL 5294762 (D.D.C. Sept. 9, 2015); see also Michael R. Crittenden \& Colleen McCain Nelson, House Authorizes Boehner to Sue President, WALl ST. J., July 31, 2014, at A4; Jeremy W. Peters, Partisanship Infuses Hearings on Health Law and Executive Power, N.Y. TIMES, July 17, 2014, at A15. The district court held that the House of Representatives has standing to bring an action over the Obama Administration's spending of unappropriated funds to implement portions of the legislation but lacked the standing to challenge the delays in implementing the statute. See Burwell, $2015 \mathrm{WL}$ 5294762 at *3-4; see also infra notes 266-82 and accompanying text.

40. See I.R.C. $\S$ 4980D(a)-(b), 9815 (2012). The excise tax imposed by I.R.C. $\S 4980 D$ predates the enactment of Patient Protection and Affordable Care Act. The excise tax is triggered by the failure of a plan to conform to the requirements of chapter 100 of the Internal Revenue Code. Id. $\S 4980 D$ (a). I.R.C. $\S 9815$ was added to chapter 100 by the Patient Protection and Affordable Care Act to incorporate its changes into chapter 100. See Patient Protection and Affordable Care Act, Pub. L. No. 111-148, § 1563(f), 124 Stat. 119, 270 (2010) (as redesignated by § 10107(b)(1), 124 Stat. at 911). Plans cannot exclude coverage of preexisting conditions, must not, in general, impose lifetime or annual limits on the dollar amount of benefits, must offer coverage to dependent children under the age of 26, and provide coverage of preventive services. See generally Temp. Treas. Reg. $\S \S 54.9815-2704 \mathrm{~T}, 2711 \mathrm{~T}, 54.9815-2714 \mathrm{~T}$ (2010); Treas. Reg. § 54.9815-2713 (2015). The I.R.S. has provided certain small employers transition relief from the excise tax until June 30, 2015. See I.R.S. Notice 2015-17, 2015-14 I.R.B. 845.

41. Burwell v. Hobby Lobby Stores, Inc., 134 S. Ct. 2751, 2762, 2769 (2014). One objective of the Patient Protection and Affordable Care Act is the provision of preventative care for women. See 42 U.S.C. $§ 300 g g-13(a)(4)$ (2012). Recommended guidelines were published on August 1, 2011 that included, as part of such preventive care, FDA-approved contraceptive methods for women, with discretionary exemptions for churches, their auxiliaries, and religious orders. See 


\section{The Tax Credit}

Federal tax credits are provided to individuals and families whose income is below a certain threshold and who pay premiums for insurance through an Exchange established by the State under section 1311 of the Patient Protection and Affordable Care Act. ${ }^{42}$ An individual who is

Women's Preventative Services Guidelines, U.S. DeP'T OF HeAlth \& HUMAN SERVs. Health ReS. AND SERVS. ADMIN., http://www.hrsa.gov/womensguidelines/ (last visited Feb. 4, 2016); 45 C.F.R. $\S 147.131$ (a) (2013) (presenting exemption and accommodations in connection with coverage of preventative health services); see also Group Health Plans and Health Insurance Issuers Relating to Coverage of Preventive Services Under the Patient Protection and Affordable Care Act, 76 Fed. Reg. 46,621, 46,623 (Aug. 3, 2011). After originally providing certain religious non-profit employers with an additional year to comply with the contraception coverage, the Obama Administration, under pressure from various religious groups, announced a compromise whereby insurance companies would provide contraception coverage for employees of certain religious non-profit employerstermed "eligible organizations"- free of charge if the employers decided not to provide such coverage. See 45 C.F.R. $§ 147.131($ b)-(c) (2015); see also Press Release, Office of the Press Sec'y, The White House, Fact Sheet: Women's Preventive Servs. and Religious Institutions (Feb. 10, 2012), https://www.whitehouse.gov/the-press-office/2012/02/10/fact-sheet-women-s-preventiveservices-and-religious-institutions. This accommodation has itself come under attack. See Wheaton Coll. v. Burwell, 134 S. Ct. 2806, 2807 (2014) (granting preliminary injunction). As a result, the Obama Administration modified the accommodation. See Treas. Reg. § 54.9815-2713AT (2014) (removed by 80 Fed. Reg. 41,318, 41,344 (2015)). No other exemptions or concessions were made for any other persons who object, on religious grounds, to the coverage of contraceptive services. The Court, in a 5-4 ruling, held that three for-profit corporations are persons for purposes of the Religious Freedom Restoration Act, that the contraception mandate imposed a substantial burden on their free exercise rights, and that the government could have achieved its asserted compelling purpose by less-restrictive means. See Hobby Lobby Stores, Inc., 134 S. Ct. at 2769, 2779, 2781-82. The I.R.S. recently issued regulations that would extend accommodations to certain closely-held forprofit entities whose highest governing body adopts a resolution that sets forth the entity's objection to the provision of some or all forms of contraception due to the owners' sincerely held religious beliefs. See Treas. Reg. $§ 54.9815-2713$ A (2015). Challenges to the accommodation have thus far proven unsuccessful. See, e.g., Little Sisters of the Poor Home for the Aged v. Burwell, 794 F.3d 1151 (10th Cir. 2015), cert. granted, 136 S. Ct. 446 (2015); Univ. of Notre Dame v. Burwell, 786 F.3d 606 (7th Cir. 2015); Priests for Life v. U.S. Dep't of Health \& Human Servs., 772 F.3d 229 (D.C. Cir. 2014), cert. granted, 136 S. Ct. 446 (2015).

42. See I.R.C. $\S 36 \mathrm{~B}(\mathrm{a}),(\mathrm{b}),(\mathrm{c})(1)(\mathrm{A})$. Advance payments of the credits may be made in the form of reductions to the monthly insurance premiums and such advance payments reduce the amount of the credit under section 36B. Id. $\S 36 \mathrm{~B}(\mathrm{f})(1)$. In the event that advances exceed the credit amount to which the taxpayer is entitled, the excess amount advanced increases the income tax owed by the taxpayer, subject to certain limitations based on the level of the taxpayer's household income. Id. $\S 36 \mathrm{~B}(\mathrm{f})(2)$; Treas. Reg. $\S 1.36 \mathrm{~B}-4$ (2012). Advance credits may yield unpleasant surprises for many taxpayers. An estimate by H\&R Block Inc. predicts that approximately 3.4 million taxpayers may have received excess advance credits. See Stephanie Armour \& Louise Radnofsky, Health Law is Creating a Trickier Tax Season, WALL St. J., Jan. 2, 2015, at A1. The I.R.S. estimates that 4.5 million taxpayers must file returns to reconcile the tax credits they received and that approximately 710,000 of these taxpayers have neither filed a return nor requested an extension. Letter from John A. Koskinen, Comm'r, I.R.S., to Sen. Orrin G. Hatch, Chairman, Comm. on Finance, U.S. Senate (July 17, 2015), http://hr.cch.com/hrw/Koskinen071715LettertoCongress.pdf. The I.R.S. has agreed to waive, for 2014, the penalties imposed by I.R.C. sections 6651(a)(2) and 6654(a) for failure to pay tax and failure to make required estimated tax payments, respectively, that are attributable to excess 
covered under any eligible employer-sponsored plan or who is offered health insurance coverage through an eligible employer-sponsored plan under which the employee's required contribution with respect to the plan does not exceed 9.5 percent of the applicable taxpayer's income and which covers at least 60 percent of total benefit costs are not eligible for the credit. $^{43}$

The credit is designed to subsidize health insurance coverage for taxpayers whose income does not exceed 400 percent of the poverty line for a family of the size involved. ${ }^{44}$ The credit is determined on a monthly basis and is the lesser of:

(A) the monthly premiums for such month for 1 or more qualified health plans offered in the individual market within a State which cover the taxpayer, the taxpayer's spouse, or any dependent ... and which were enrolled in through an Exchange established by the State ... or (B) the excess (if any) of the adjusted monthly premium for such month

advance credits for taxpayers who are otherwise current in their tax liabilities and who properly report the excess credits on their tax returns. See I.R.S. Notice 2015-9, 2015-6 I.R.B. 590. The federal government has experienced difficulty in properly reporting the credits to which taxpayers are entitled in 2014. See What Consumers Need to Know About Corrected Form 1095-As, THE CMS BLOG (Feb. 20, 2015), http://blog.cms.gov/2015/02/20/what-consumers-need-to-know-aboutcorrected-form-1095-as/. As a result, the I.R.S. will not impose penalties on taxpayers who received erroneous credit information or collect additional taxes from taxpayers who filed returns using erroneous credit information. See Questions and Answers - Incorrect Forms 1095-A and the Premium Tax Credit, I.R.S. (Jan. 26, 2016), http://www.irs.gov/Affordable-Care-Act/Individualsand-Families/Questions-and-Answers-Incorrect-Forms-1095A-and-the-Premium-Tax-Credit; see also Stephanie Armour, Taxpayers Set to Get a Health Break, WALl St. J., Feb. 25, 2015, at A3.

43. See I.R.C. $\S 36 \mathrm{~B}(\mathrm{c})(2)$. A taxpayer also is ineligible for the credit if she is offered minimum essential coverage other than such coverage through the individual market. See id. $\S$ $36 \mathrm{~B}(\mathrm{c})(2)(\mathrm{B})$.

44. See id. $\S 36 \mathrm{~B}(\mathrm{c})(1)(\mathrm{A})$. Except for aliens lawfully present in the United States and ineligible for Medicaid benefits, taxpayers whose incomes are below 100 percent of the federal poverty line do not qualify for credits or cost sharing reductions. See id. $\S 36 \mathrm{~B}(\mathrm{c})(1)(\mathrm{B})$. Generally, such taxpayers would qualify for Medicaid benefits. However, the Patient Protection and Affordable Care Act's expansion of Medicaid was held unconstitutional because it was considered impermissibly coercive to the states. See Nat'l Fed'n of Indep. Bus. v. Sebelius, 132 S. Ct. 2566, 2606-07 (2012). Consequently, states could opt to decline to expand Medicaid eligibility without the loss of federal funds provided under existing programs. See id. at 2607. As a result, it is possible that some taxpayers will be ineligible for the tax credits and cost sharing reductions and not be eligible for Medicaid benefits if they reside in a state that chose not to expand Medicaid coverage. Twenty-eight states and the District of Columbia have chosen to expand Medicaid eligibility, and Alaska and Montana appear likely to do so. Louise Radnofsky, Alaska Governor Moves to Expand Medicaid, WALL ST. J., July 17, 2015, at A3. Indiana recently expanded its Medicaid program under an agreement with the federal government that would permit the state to require Medicaid enrollees to contribute toward the cost of medical insurance coverage. Louise Radnofsky \& Arian CampoFlores, Deal Offers Model for Medicaid Expansion, WALL ST. J., Jan. 28, 2015, at A1. Individuals covered under a state Medicaid program may find access to medical services more difficult because of drastic cuts in Medicaid reimbursement rates. See Robert Pear, As Medicaid Rolls Swell, Cuts in Payments to Doctors Threaten Access to Care, N.Y. TIMES, Dec. 28, 2014, at A20. 
for the applicable second lowest cost silver plan with respect to the taxpayer, over... 1/12 of ... [a percentage of the] taxpayer's household income for the taxable year. ${ }^{45}$

In effect, the credit subsidy is limited to the excess of the premium cost of a baseline plan over a percentage, which increases as the taxpayer's household income approaches 400 percent of the poverty line, of the taxpayer's household income. ${ }^{46}$

The allowance of a tax credit can trigger the applicability of the individual mandate with respect to the individual entitled to the credit. ${ }^{47}$ The allowable credit reduces such an individual's required contribution for purposes of determining whether insurance coverage is affordable by such individual and, therefore, mandated. ${ }^{48}$ In addition, the penalty imposed on employers by section $4980 \mathrm{H}$ is triggered by the attainment of a credit or cost sharing reduction by one employee. ${ }^{49}$ Section 36B's language appears to limit eligibility for a tax credit to taxpayers who are enrolled in State Exchanges. ${ }^{50}$ However, regulations were issued pursuant to those participants in Federal Exchanges who would also qualify for the credit. ${ }^{51}$ Sylvia Burwell, Secretary of Health and Human Services, stated that approximately 87 percent of Federal Exchange

45. I.R.C. $\$ 36 \mathrm{~B}(\mathrm{~b})(2)$. In the event that a qualified health plan offers benefits in addition to the essential health benefits required to be provided by the plan or a state requires that such additional benefits be provided under the plan, the portion of the premium properly allocable to such additional benefits are not taken into account. Id. $\S 36 \mathrm{~B}(\mathrm{~b})(3)(\mathrm{D})$; see supra note 28 (explaining silver plans).

46. The applicable percentage varies from a minimum of 2 percent to a maximum of 9.5 percent, subject to adjustment after 2014 to account for the possibility that health insurance costs increase faster than the rate of income growth. I.R.C. $\$ 36 \mathrm{~B}(\mathrm{~b})(3)(\mathrm{A})$. Additional adjustments are to be made beginning in 2019 if premium cost increases exceed the growth in the consumer price index and the subsidies exceed a certain level of gross domestic product. Id. $\S 36 \mathrm{~B}(\mathrm{~b})(3)(\mathrm{A})(\mathrm{ii})$. Household income is the sum of the modified adjusted gross income of all individuals who were taken into account in determining the taxpayer's family size and were required to file a tax return for the taxable year. $I d . \S 36 \mathrm{~B}(\mathrm{~d})(2)(\mathrm{A})$. Modified adjusted gross income is adjusted gross income plus foreign income excluded under I.R.C. section 911, tax-exempt interest, and non-taxable social security benefits. Id. $\S 36 \mathrm{~B}(\mathrm{~d})(2)(\mathrm{B})$. The federal poverty line is the most recently published poverty guidelines as of the first day of the regular enrollment period for coverage through an Exchange for the calendar year. Id. $\$ 36 \mathrm{~B}(\mathrm{~d})(3)$.

47. See supra note 35 and accompanying text.

48. See I.R.C. $\$ 5000 A(e)(1)(B)(i i)$.

49. See supra note 36 and accompanying text.

50. See supra note 42 and accompanying text.

51. See Treas. Reg. $\S 1.36 \mathrm{~B}-1(\mathrm{k})$ (2012) (defining Exchange by reference to 45 C.F.R. 155.20 (2012)), id. $\S 1.36$ B-2(a) (providing eligibility for credit by enrollment in an Exchange); 45 C.F.R. $\S$ 155.20 (2012) (stating that the term Exchange refers to State Exchanges, regional Exchanges, subsidiary Exchanges, and a Federally-facilitated Exchange). 
enrollees qualified for tax credits. $^{52}$ According to the Congressional Budget Office, the average tax credit for 2014 was $\$ 4,330 .{ }^{53}$

\section{COURT DECISIONS}

\section{A. Circuit Court Split}

Several Virginia residents challenged the validity of the regulations that entitled qualified enrollees on Federal Exchanges to tax credits. $^{54}$ Virginia did not establish an Exchange, and the Federal Exchange, HealthCare.gov, serves its residents. ${ }^{55}$ The availability of credits pursuant to the regulations caused these Virginia residents to be subject to the individual mandate because the allowable credits rendered their insurance costs affordable under the statute. ${ }^{56}$ The Fourth Circuit unanimously affirmed the district court's holding that the statute as a whole evinced Congress's intent to make the credits available nationwide and, consequently, the regulations were within the Treasury's authority. ${ }^{57}$

The court applied the two-step framework set forth in Chevron, U.S.A., Inc. v. Natural Resource Defense Council, Inc. ${ }^{58}$ First, the court held that the statutory language did not clearly and unambiguously reveal the intent of Congress with respect to the availability of tax credits for individuals enrolled on Federal Exchanges. ${ }^{59}$ Although the language of section $36 \mathrm{~B}$ clearly referred only to Exchanges established by a state, the court refused to "confine itself to examining a particular statutory provision in isolation." 60 The court believed that section 1311, the

52. Press Release, Dep't of Health \& Human Servs., 87 Percent of People Who Selected 2015 Plans Through HealthCare.gov in First Month of Open Enrollment Are Getting Financial Assistance to Lower Monthly Premiums (Dec. 30, 2014), http://www.hhs.gov/about/news/2014/12/30/87percent-people-who-selected-2015-plans-through-healthcaregov-first-month-open-enrollmentare.html. Approximately 86 percent of all enrollees, whether enrolled on State or Federal Exchanges, receive subsidies. Pear, supra note 19, at A17.

53. Louise Radnofsky, Republicans to Block Legislative Fix to Health-Care Law, WALL ST. J. (Jan. 29, 2015, 6:53 PM), http://www.wsj.com/articles/republicans-to-block-legislative-fix-to-healthcare-law-1422575627.

54. See King v. Sebelius, 997 F. Supp. 2d 415, 427 (E.D. Va. 2014), aff'd sub nom. King v. Burwell, 759 F.3d 358 (4th Cir. 2014), aff'd, 135 S. Ct. 2480 (2015).

55. Id. at 419 .

56. Id. at 420-21. See also supra notes $47-48$ and accompanying text.

57. King v. Burwell, 759 F.3d 358, 363, 369 (4th Cir. 2014), aff'd, 135 S. Ct. 2480 (2015).

58. Id. at 367. See infra note 69 for a discussion of the application of the Chevron framework to tax regulations.

59. King, 759 F.3d at 369 .

60. Id. at 368 (quoting Nat'l Ass'n of Home Builders v. Defs. of Wildlife, 551 U.S. 644, 666 
provision authorizing State Exchanges, section 1321, the provision authorizing Federal Exchanges, and a definitional provision of the Act could plausibly be read to treat Federal Exchanges as Exchanges established by a state. ${ }^{61}$ In effect, all Exchanges are State Exchanges. ${ }^{62}$

The court also found that two other statutory provisions were irreconcilable with the appellants' assertion that section 36B denies the availability of credits to taxpayers enrolled on Federal Exchanges. First, the information reporting requirements of section 36B apply to all Exchanges and these requirements mandate the reporting of credit information. ${ }^{63}$ The court believed that the imposition of such a reporting requirement on Federal Exchanges belied the notion that credits are unavailable to taxpayers enrolled through such Exchanges. ${ }^{64}$ Secondly, only "qualified individuals" are eligible to purchase insurance from the Exchanges and, because such term is defined as a person who resides in the state that established the Exchange, the appellants' interpretation of the statute would leave a Federal Exchange with no eligible customers. ${ }^{65}$

The court found little guidance in the legislative history of the statute. Several floor statements by Senators indicated that all taxpayers would have access to the credits. ${ }^{66}$ However, such statements could have been made under the assumption that all states would establish Exchanges and that denying credits to taxpayers that enrolled through Federal Exchanges would serve as an inducement to states to establish their own Exchanges. ${ }^{67}$

\footnotetext{
(2007)).

61. Id. at 369 .

62. $I d$.

63. Id. at $369-70$.

64. Id. at 370 .

65. Id. at $370-71$.

66. Id. at 371 .

67. Id. at 371-72. There is evidence that the Obama Administration assumed that states would create Exchanges.

So this really starts at the States. States put together exchanges either as a single State or in a multi-State area, if that is what they choose. We provide technical assistance to the States to do that. And even though the timetable for exchanges doesn't begin until 2014, we intend, starting next year, to begin very robust discussions so that we don't wait until the last minute and have States in a situation where they can't do this.

We have already had lots of positive discussions, and States are very eager to do this. And I think it will very much be a State-based program. And particularly, Congressman, it is not to dismantle what is in place right now. It is really to replace the market for selfemployed Americans, many of whom cannot find affordable coverage, don't have any leverage, a lot of small-business owners who find themselves in the same situation. 
Having found that Congress did not speak directly to the precise issue raised by the appellants, the court proceeded to the second prong of Chevron's framework-a determination of whether the regulations were based on a permissible construction of the statute. ${ }^{68}$ Under Chevron, a court will not disturb an agency's interpretative authority so long as the interpretation is not " "arbitrary, capricious, or manifestly contrary to the statute." reasonably accommodative of conflicting policies committed to an agency's care by the statute will be upheld. ${ }^{70}$ Ambiguities in a statute may be resolved through consideration of policy arguments rationally related to the statute's goals. ${ }^{71}$ In this case, the objectives of the Patient Protection and Affordable Care Act are to increase the number of Americans covered by health insurance and to decrease the cost of health care. $^{72}$ According to the court, the broad availability of tax credits to

for 2011: Hearings Before a Subcomm. of the H.R. Comm. on Appropriations, 111th Cong. 171 (2010) (statement of Kathleen Sebelius, Sec'y, Dep't of Health \& Human Servs.) (emphasis added), http://www.gpo.gov/fdsys/pkg/CHRG-111hhrg58233/pdf/CHRG-111hhrg58233.pdf.

68. King, 759 F.3d at 372.

69. Id. (quoting Philip Morris USA, Inc. v. Vilsack, 736 F.3d 284, 290 (4th Cir. 2013) (quoting Chevron, U.S.A., Inc. v. Nat. Res. Def. Council, Inc., 467 U.S. 837, 844 (1984))). The appellants asserted that the Exchanges are administered by the Department of Health and Human Services and, therefore, the I.R.S. did not have the authority to issue the regulations in question. Id. at 375 . The court rejected this assertion because I.R.C. $\S 36 \mathrm{~B}$ delegated to the I.R.S. the authority to resolve ambiguities in the statute. Id. The appellants further asserted that Chevron deference does not apply because tax credits and exemptions are to be construed narrowly. Id. According to the court, Chevron deference is not displaced in tax matters and in fact, this was reaffirmed by the Supreme Court in Mayo Foundation for Medical Education \& Research v. United States. Id. at 375-76. Prior to Chevron, the Court applied a less deferential, multi-factor test to determine whether agency regulations were a permissible interpretation of a statute. Nat'l Muffler Dealers Ass'n v. United States, 440 U.S. 472, 477 (1979). Under this test - the so-called National Muffler test, the courts examined whether the regulations in question were a contemporaneous construction of the statute promulgated with the awareness of congressional intent; the length of time that the regulations were in effect; the degree of reliance placed on the regulations by affected parties; the consistency of the agency's position; and the degree of scrutiny given the regulations by Congress during subsequent re-enactments of the statute. Id. After Chevron, the Court continued to apply the National Muffler test to Treasury regulations issued under the general statutory grant of authority under I.R.C. § 7805 and limited Chevron deference to Treasury regulations issued under a specific statutory grant of authority. See, e.g., United States v. Vogel Fertilizer Co., 455 U.S. 16, $24-25$ (1982); Rowan Cos. v. United States, 452 U.S. 247, 253 (1981). However, the Court did away with the distinction between these two types of Treasury regulations in Mayo and held that the Chevron standard applied to all Treasury regulations because it acknowledged that the administrative landscape had changed over the years and that no special rules were warranted for tax regulations. See Mayo Found. for Med. Educ. \& Research v. United States, 562 U.S. 44, 55-57 (2011). Accordingly, like any other agency regulations, tax regulations, regardless of their source of authority, are entitled to Chevron deference. See id.

70. King, 759 F.3d at 372-73.

71. Id. at 373 .

72. See id. at $373-74$. 
subsidize the cost of health insurance is congruent with the statute's objectives. $^{73}$

In Halbig v. Burwell, the D.C. Circuit had before it a similar challenge to the I.R.S. regulations brought by individual appellants who resided in states that did not establish Exchanges. ${ }^{74}$ In a 2-1 decision, the D.C. Circuit reversed the district court's judgment upholding the validity of the regulations. ${ }^{75}$ Unlike the Fourth Circuit, the court found no need to proceed to the second prong of the Chevron framework because it believed that Congress did speak directly to the precise question at issue. ${ }^{76}$ According to the D.C. Circuit, Federal Exchanges are equivalent to State Exchanges in certain respects, but they differ from State Exchanges in one crucial respect. ${ }^{77}$ They are not established by a state as required by the language of section $36 \mathrm{~B} .{ }^{78}$ Section 1321 of the Patient Protection and Affordable Care Act, the provision that authorizes Federal Exchanges, omits any language that suggests that such Exchanges should be treated as State Exchanges. ${ }^{79}$ Moreover, the D.C. Circuit noted Congress was capable of establishing equivalency between Exchanges as evidenced by the statutory language creating such equivalency with respect to Exchanges established in possessions of the United States. ${ }^{80}$ Congress's use of dissimilar language in different parts of a statute is presumed intentional. ${ }^{81}$ The D.C. Circuit also rejected the government's contention that all Exchanges are, by definition, established by a state. ${ }^{82}$

The D.C. Circuit then proceeded to examine whether the so-called absurdity doctrine was applicable. ${ }^{83}$ This doctrine avoids statutory constructions that would render a statute nonsensical, superfluous, or would result in an outcome so contrary to perceived social values that

73. Id. at 374-75.

74. 758 F.3d 390, 393 (D.C. Cir. 2014), rev'g Halbig v. Sebelius, 27 F. Supp. 3d 1 (D.D.C. 2014). The decision of the court was vacated and a rehearing en banc was granted. Halbig v. Burwell, No. 14-5018, 2014 WL 4627181 (D.C. Cir. Sept. 4, 2014). However, the case subsequently was held in abeyance pending the decision of the Supreme Court. Halbig v. Burwell, No. 14-5018, 2014 WL 7520425 (D.C. Cir. Nov. 12, 2014).

75. See Halbig, 758 F.3d at 394, 412.

76. See id. at $398-99$.

77. Id. at 400 .

78. Id.

79. See id. See also supra notes $15-18$ and accompanying text.

80. See Halbig, 758 F.3d at 400.

81. See id. (citing Nat'l Fed'n of Indep. Bus. v. Sebelius, 132 S. Ct. 2566, 2583 (2012)).

82. Id. at $400-02$.

83. Id. at 402,405 . 
such an interpretation belies congressional intent. ${ }^{84}$ In deference to separation of powers principles, however, this doctrine is narrowly applied, requiring a "'high threshold' of unreasonableness before we conclude that a statute does not mean what it says."

In contrast to the Fourth Circuit, the D.C. Circuit did not consider the reporting obligations imposed by section $36 \mathrm{~B}$ on all Exchanges as evidence that Congress intended that tax credits be available to enrollees on Federal Exchanges. ${ }^{86}$ The reporting obligations go well beyond tax credit information and the fact the tax credits are unavailable for individuals enrolled on Federal Exchanges does not render these obligations nonsensical in the context of such Exchanges. The reporting obligations merely render the statute over-inclusive - a problem that exists in section 36B whether or not tax credits were available to enrollees on all Exchanges. ${ }^{87}$ The D.C. Circuit also rejected the government's assertion that its construction of the statute would leave Federal Exchanges without any eligible customers. ${ }^{88}$ According to the D.C. Circuit, such Exchanges could have customers. ${ }^{89}$ These customers would not be "qualified individuals" but they would be customers nonetheless. ${ }^{90}$ Finally, the D.C. Circuit rejected the government's contention that its construction of the statute would impose a perpetual obligation on states that declined to establish Exchanges to refrain from tightening their Medicaid eligibility rules. ${ }^{91}$ Such an obligation is imposed on a state until it has established a fully operational Exchange. ${ }^{92}$ However, the reservation of Medicaid benefits for residents of a state for which no tax subsidy is available appeared logical to the D.C. Circuit. ${ }^{93}$

Despite the fact that the court believed that the statutory language was unambiguous, it did proceed to examine the legislative history of the statute in an attempt to glean some kernel of congressional intent-a task it did not concede was necessary in this case. ${ }^{94}$ The best evidence of

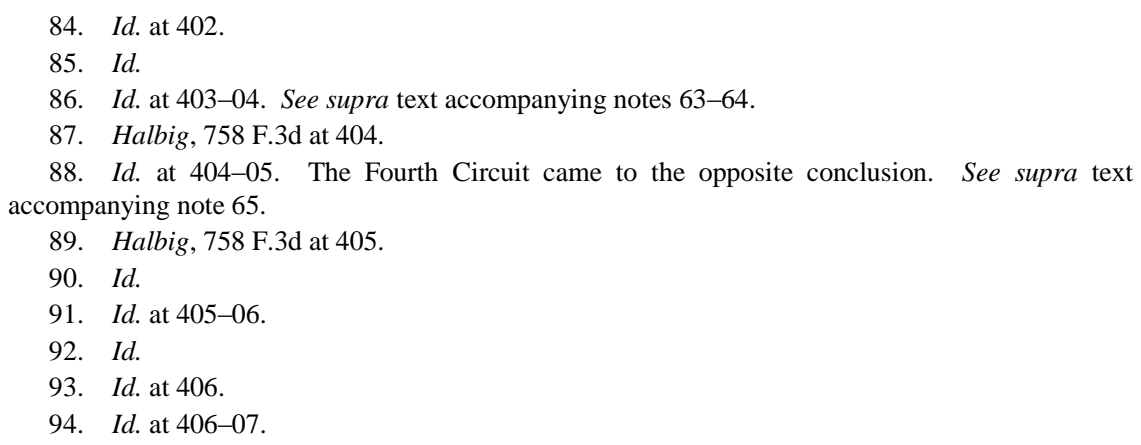


congressional intent is the legislation that Congress enacted. ${ }^{95}$ Legislative history, which has a secondary role in discerning such intent, is to be enlisted only when the "literal application of a statute will ... produce a result demonstrably at odds with the intentions of its drafters." $" 96$ Quoting from its own precedent, the D.C. Circuit stated that it should depart from the plain meaning of statutory language only upon a "most extraordinary showing of contrary intentions."

In the D.C. Circuit's opinion, the legislative history failed to provide demonstrable evidence that Congress intended to provide tax credits to eligible enrollees on all Exchanges. ${ }^{98}$ The D.C. Circuit found the legislative history inconclusive in this respect and believed that a reasonable inference could be drawn that the limitation of credits to enrollees on State Exchanges was a means to incentivize states to establish their own Exchanges. ${ }^{99}$ The D.C. Circuit, moreover, refused to countenance the absence of any suggestion in the legislative history that credits be so limited as evidence of an intent to the contrary. ${ }^{100}$ Silence is not evidence Congress meant something other than what it said. ${ }^{101}$

The D.C. Circuit also rejected the government's argument that the broad purposes of the Patient Protection and Affordable Care Act-near universal health insurance coverage and lower costs for such coverageevidenced that Congress had no intention to limit tax credits to individuals enrolled through State Exchanges. ${ }^{102}$ Despite the fact that the individual mandate, the insurance subsidies, and the insurance market reforms work together as a cohesive scheme to achieve the legislation's purposes, the legislation itself belies the government's contention that the limitation on the tax credits urged by the appellants would have been

\footnotetext{
95. Id. at 407 .

96. Id. (quoting Engine Mfrs. Ass'n, ex. rel. Certain of its Members v. EPA, 88 F.3d 1075, 1088 (D.C. Cir. 1996)).

97. Id. (quoting Garcia v. United States, 469 U.S. 70, 75 (1984)).

98. Id. at 407-08.

99. See id. at 408 .

100. See id. In the Explanation of Provisions and Summary of Comments that accompanied the issuance of the final regulations, the I.R.S. did not cite to any specific statutory provision, other than a general reference to I.R.C. $\S 36 \mathrm{~B}$ itself, in support of its position. Instead, it justified its position by reference to "other provisions of the Affordable Care Act" and by the fact that "the relevant legislative history does not demonstrate that Congress intended to limit the premium tax credit to State Exchanges." Health Insurance Premium Tax Credit, 77 Fed. Reg. 30377, 30378 (May 23,

101. Halbig, 758 F.3d at 408.

102. Id. at $408-09$.
} 2012). 
inconceivable to Congress. ${ }^{103}$ The legislation exempted residents of select United States territories from the individual mandate, yet the insurance market reforms were made applicable to these territories. ${ }^{104}$ The adverse selection problem caused by having the insurance reforms without a corresponding individual mandate was also in evidence in the long-term care provisions of the legislation that Congress repealed in 2013. ${ }^{105}$ Whether or not Congress tolerated an adverse selection problem in the territories because it represented only a small segment of the insurance market or whether Congress was willing to tolerate such a problem more broadly is a question that the legislative history leaves unanswered. ${ }^{106}$

\section{B. Supreme Court Decision}

On June 25, 2015, in King v. Burwell, the United States Supreme Court affirmed the judgment of the Fourth Circuit and held that enrollees on Federal Exchanges are indeed entitled to tax credits in a 6-3 decision. ${ }^{107}$ Justice Roberts, who wrote for the Court, briefly reviewed the economic underpinnings of the legislation. He noted that earlier efforts by various states to expand individuals' access to health insurance coverage failed to achieve their objectives. ${ }^{108}$ These efforts coupled some form of guarantee issue and community rating requirements to assure that health insurance coverage was available to individuals seeking coverage and that such coverage was not denied or discriminately priced due to pre-existing medical conditions. ${ }^{109}$ However, these reforms sowed the seeds of their own failure. Guarantee issue and community rating rules assured that insurance would be available, at a reasonable price, when needed, thereby exacerbating the phenomenon of adverse selection-the propensity for individuals to purchase insurance when they become ill. ${ }^{110}$ As a result, the insured pool increasingly skewed toward the sick causing premiums to rise and thus further encouraging adverse selection. This process, referred to by Chief

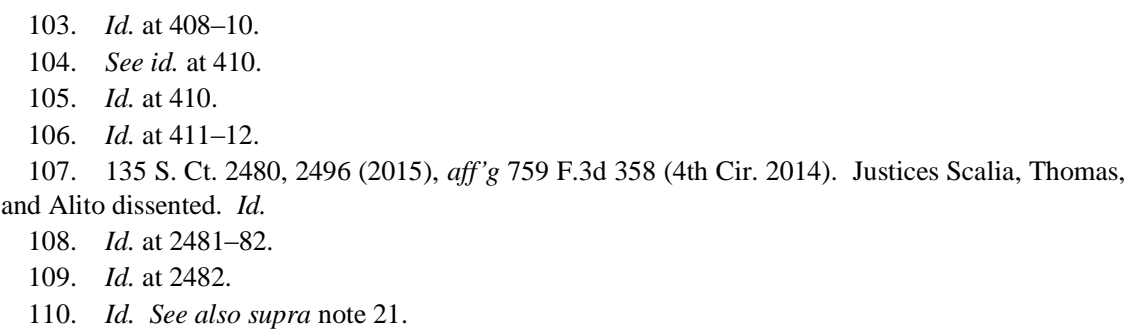


Justice Roberts as a "death spiral," eventually led to insurers abandoning the market altogether, and, as a consequence, the number of uninsured individuals increased significantly. ${ }^{111}$

Chief Justice Roberts contrasted the experience of the states of Washington and New York, both of which experienced this "death spiral" after enacting reforms in the 1990s, with the Commonwealth of Massachusetts. $^{112}$ Like Washington and New York, Massachusetts adopted guarantee issue and community rating requirements in the 1990s, but unlike her sister states, Massachusetts later required individuals to purchase insurance or otherwise face a financial penalty and provided tax credits to subsidize the cost of the mandated insurance to certain individuals. ${ }^{113}$ These additional measures proved successful, and the number of uninsured individuals in Massachusetts fell to the lowest rate in the nation. ${ }^{114}$ The combination of guarantee issue and community rating to make insurance available, mandatory coverage to reduce adverse selection, and subsidies to increase affordability underpins the Patient Protection and Affordable Care Act. ${ }^{115}$

Chief Justice Roberts proceeded to analyze the I.R.S.'s interpretation of section 36B. Unlike the Fourth Circuit, the Court did not examine the regulation through the lens of Chevron. ${ }^{116}$ According to the Court, the deference afforded administrative agencies in their interpretations of statutory ambiguities under Chevron is premised on the notion that such ambiguities constitute "an implicit delegation from Congress to the agency to fill in the statutory gaps." 117 This implication may be unwarranted in "extraordinary cases" and, according to the Chief Justice Roberts, this legislation is one such case. ${ }^{118}$ Chief Justice Roberts stated:

The tax credits are among the Act's key reforms, involving billions of dollars in spending each year and affecting the price of health insurance for millions of people. Whether those credits are available on Federal Exchanges is thus a question of deep "economic and political

\footnotetext{
111. King, 135 S. Ct. at $2485-86$.

112. Id. at 2486 .

113. Id

114. Id. (citing Examining Individual State Experiences with Health Care Reform Coverage Initiatives in the Context of National Reform: Hearing Before the S. Comm. on Health, Educ., Labor, \& Pensions, 111th Cong. 9 (2009)).

115. Id. at 2493.

116. See id. at $2488-89$.

117. Id. at 2488 (quoting FDA v. Brown \& Williamson Tobacco Corp., 529 U.S. 120, 159 (2000)).

118. Id. at 2488-89 (quoting Brown \& Williamson Tobacco Corp., 529 U.S. at 159).
} 
significance" that is central to this statutory scheme; had Congress wished to assign that question to an agency, it surely would have done so expressly. It is especially unlikely that Congress would have delegated this decision to the IRS, which has no expertise in crafting health insurance policy of this sort. This is not a case for the IRS.

The Court noted that statutory language that is plain is enforceable according to its terms, but whether such language is, in fact, plain "may only become evident when placed in context ... and with a view to their place in the overall statutory scheme." 120 The Court examined the definitional provisions of the statute and, similar to the Fourth Circuit, found that the most natural meaning of the definitional provisions would result in no qualified individuals on Federal Exchanges and that Federal Exchanges would not be Exchanges at all-results clearly not contemplated by the statute. ${ }^{121}$ Moreover, unless Federal Exchanges are deemed established under the same statutory provision as State Exchanges, none of the statutory requirements are applicable to the Federal Exchanges. ${ }^{122}$ In addition, the Court agreed with the Fourth Circuit that the information reporting requirements imposed on Federal Exchanges made little sense if tax credits were not available to enrollees on such Exchanges. ${ }^{123}$

The Court found it possible to interpret the language of section 36B either to limit tax credits to enrollees in State Exchanges or to permit enrollees on both State and Federal Exchanges to qualify for tax credits. $^{124}$ However, the Court determined that the statute intended equivalency between the two types of Exchanges. ${ }^{125}$ Denying tax credits to enrollees on Federal Exchanges would create a fundamental difference

119. Id. at 2489 (citations omitted).

120. Id. (quoting Brown \& Williamson Tobacco Corp., 529 U.S. at 132-33). The admonition that language must be placed in context reminds me of a scene from the motion picture, The Paper Chase. THE PAPER CHASE (20th Century Fox 1973), http://www.springfieldspringfield.co.uk/movie_script.php?movie=paper-chase-the. In the scene, a third-year law student tutors one of the main characters, a first-year law student. See id. The thirdyear law student poses a hypothetical case to the first-year law student. Id. In the hypothetical, a statute requires that premises be maintained so that they are free from dangerous ice. Id. Would this statute apply if someone slipped on an ice cube in your home? Id.

121. Id. at 2490-91; see also King v. Burwell, 759 F.3d 358, 368-70 (4th Cir. 2014), aff'd, 135 S. Ct. 2480 (2015)

122. King, 135 S. Ct. at 2491.

123. Id. at 2491-92.

124. Id. at 2491.

125. Id. at 2489. 
between the two types of Exchanges. ${ }^{126}$ State Exchanges would help make health insurance affordable and Federal Exchanges would not. ${ }^{127}$ The Court rejected the notion that if Congress intended the tax credits to be available for qualified individuals enrolled on all Exchanges then the words "established by the State" would have been unnecessary. ${ }^{128}$ The Court noted that its preference for the avoidance of surplusage is not an absolute rule and that the application of such preference was particularly unwarranted in this case. ${ }^{129}$ The legislation was poorly drafted due, in large part, to the political machinations that were employed in order to secure its passage. ${ }^{130}$ Accordingly, the Court found the phrase "an Exchange established by the State" to be ambiguous. ${ }^{131}$

As previously noted, the Court did not defer to the I.R.S. for the resolution of the statute's ambiguity. ${ }^{132}$ Instead, it turned to the broader structure of the legislation to clarify the ambiguity. ${ }^{133}$ According to the Court, a limitation of tax credits to enrollees on State Exchanges would "likely create the very 'death spirals' that Congress designed the Act to avoid." 134 Such an interpretation would run counter to the canon that federal statutes cannot be interpreted to negate their own stated purpose. ${ }^{135}$ The Court rejected the assertion that Congress believed that the absence of tax credits for Federal Exchanges would entice the states to establish their own Exchanges. ${ }^{136}$ In contrast, the Court determined that the establishment of Federal Exchanges as a response to a state's unwillingness to establish its own Exchange was evidence that Congress did, in fact, contemplate state reluctance to cooperate and created a fallback to deal with such reluctance. ${ }^{137}$

Finally, the Court delved into the intricacies of section 36B and noted that the denial of tax credits to enrollees on Federal Exchanges, if such credits are to be denied, becomes evident only after delving into a

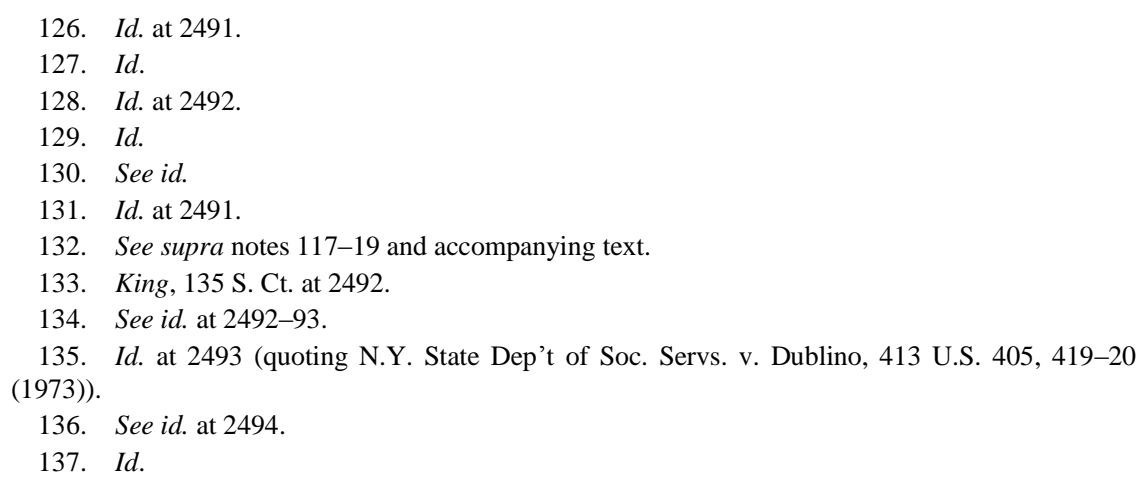


"sub-sub-sub section" of the statute. ${ }^{138}$ Due to the fundamental importance of the tax credits to the overall statutory scheme, the Court noted that a congressional intent to deny such credits would have been made known in a prominent way and not buried in the interstices of the statute. $^{139}$ Invoking Marbury v. Madison, the Court determined its resolution of the ambiguity in favor of the government prevented the undoing of the legislation, thereby respecting the role of the legislative branch. $^{140}$

The dissenting opinion, authored by Justice Scalia, acerbically disagreed with the majority's conclusion. Justice Scalia wrote that Congress could not have "come up with a clearer way to limit tax credits to [S] tate Exchanges than to use the words "established by the State.",141 The dissent conceded that statutory interpretation should not take place in isolation and that context always is a relevant consideration. ${ }^{142}$ However, context "is a tool for understanding the terms of the law, not an excuse for rewriting them." "143 Justice Scalia disagreed with the Chief Justice's belief that the phrase "established by the State" was surplusage caused by the circumstances surrounding the passage of the legislation. ${ }^{144}$ Lawmakers commonly use redundant language, according to Justice Scalia, but the majority rendered the phrase in question a nullity thereby violating a virtually absolute principle of statutory construction. ${ }^{145}$ Moreover, this language was repeated seven times throughout the statute, but it was not repeated throughout the entire statute. ${ }^{146}$ Common sense dictates that the use of a phrase in some cases and another phrase in other cases indicates that the two phrases have contrasting meanings. ${ }^{147}$

The dissent also argued that the majority's interpretation rendered various statutory provisions nonsensical. ${ }^{148}$ Several provisions of the legislation mandated state officials to undertake certain tasks related to the administration of Exchanges. ${ }^{149}$ The dissent questioned how a state

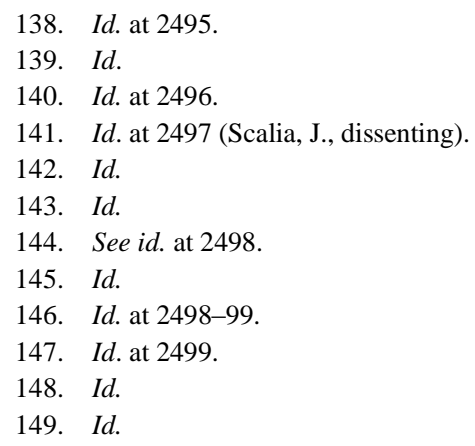


official possibly could undertake those tasks for an Exchange operated by the federal government. ${ }^{150}$ The dissent also disagreed that the statutory language evidences the intent to treat Federal and State Exchanges as equivalent. ${ }^{151}$ Whether or not Federal Exchanges were authorized as a fallback in the event of state inertia, a Federal Exchange is not a State Exchange. ${ }^{152}$ Invoking the principle that specific terms govern over general terms, even if it were true that Congress intended to equate the two types of Exchanges in general, for the specific purpose of the tax credits the two types of Exchanges are not equivalent. ${ }^{153}$ The fact that a limitation of tax credits to enrollees on State Exchanges would leave Federal Exchanges with no qualified individuals did not move the dissent. ${ }^{154}$ In fact, the majority's reliance on this result to come to a contrary conclusion was, according to Justice Scalia, "[p]ure applesauce." ${ }^{155}$ The dissent stated:

Imagine that a university sends around a bulletin reminding every
professor to take the "interests of graduate students" into account when
setting office hours, but that some professors teach only
undergraduates. Would anybody reason that the bulletin implicitly
presupposes that every professor has "graduate students" so that
"graduate students" must really mean "graduate or undergraduate
students"? Surely not. Just as one naturally reads instructions about
graduate students to be inapplicable to the extent a particular professor
has no such students, so too would one naturally read instructions about
qualified individuals to be inapplicable to the extent a particular
Exchange individuals.

Moreover, the dissent, unlike the majority, found nothing unusual in the structure of section 36B. The fact that the limitation of tax credits to enrollees on State Exchanges, if such limitation did indeed apply, is found in a formula provision - a sub-sub-sub section according to the majority - rather than a definitional provision is of no moment. ${ }^{157}$ Such

\footnotetext{
150. Id.

151. See id.

152. See id. at 2500.

153. Id. The dissent drew an analogy to Article I, section 4 of the Constitution that the dissenting Justices believed authorized Congress to regulate elections as a fallback to state action. Id. at 2499-2500.

154. Id. at 2501 .

155. Id.

156. Id.

157. Id. at $2495,2501-02$.
} 
drafting is not unusual in the Internal Revenue Code. ${ }^{158}$

Justice Scalia then directed his attention to the legislation's design and purpose and was similarly critical of the majority's conclusions in this respect. ${ }^{159}$ The notion that the health insurance market would be destabilized by the lack of tax subsidies to enrollees on Federal Exchanges, if true, merely reveals a flaw in the law and is not proof that the statute does not mean what it says. ${ }^{160}$ Moreover, this flaw existed, without dispute, in the long-term care insurance program established by the legislation and in the general insurance market in the Federal Territories. ${ }^{161}$ Justice Scalia proceeded to accuse the majority of considering the law's "purpose[s] in isolation" and ignoring other competing purposes. ${ }^{162}$ The Patient Protection and Affordable Care Act displays "a congressional preference for state participation in the establishment [and management] of Exchanges."163 The majority's conclusion frustrates this goal. ${ }^{164}$ In fact, a contrary holding would encourage states to establish their own Exchanges thereby achieving the market reforms desired with active state participation. ${ }^{165}$

Finally, the dissent took umbrage at the majority's reaction to its conclusion that this dispute was the result of inartful drafting caused, in part, by Congress's lack of due care and deliberation. ${ }^{166}$ It is not the role of the Court to amend a law that says what Congress did not intend to say or "to make everything come out right when Congress does not do its job properly."167 Justice Scalia, referring to this case and National Federation of Independent Business $v$. Sebelius, concluded by accusing the majority of results-driven jurisprudence. ${ }^{168}$ "We should start calling this law SCOTUScare.... And the cases will publish forever the discouraging truth that the Supreme Court of the United States favors some laws over others, and is prepared to do whatever it takes to uphold and assist its favorites." 169

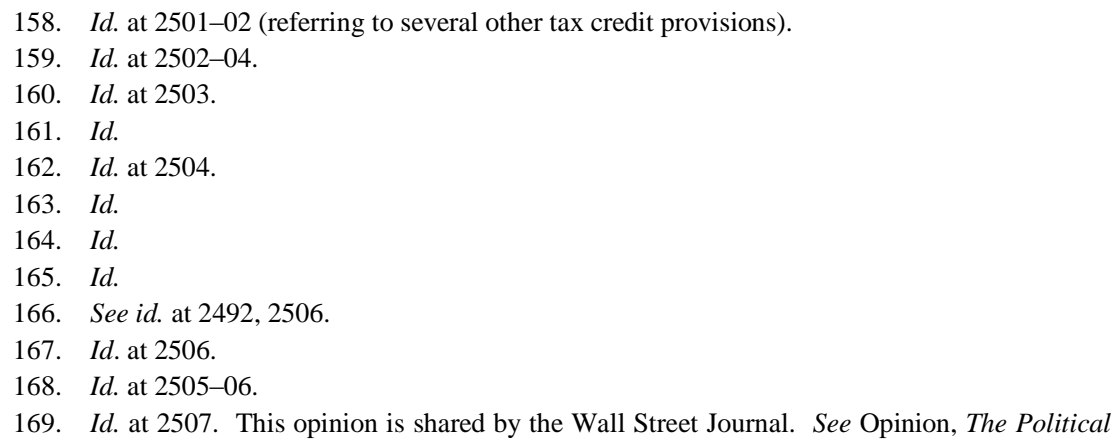


Both the majority and dissenting opinions, enlisting as they did an array of canons of statutory interpretation, are persuasive. I suspect I am not the only person whose agreement or disagreement with the Court's holding is largely dependent on pre-existing policy preferences and, perhaps, political ideology. However, the Court's handling of the Chevron issue raises troubling separation of powers issues. Moreover, the Court's standing jurisprudence is difficult to square with its handling of this issue.

\section{DISCUSSION}

\section{A. Chevron and the "Extraordinary" Case}

Prior to the Court's decision in Chevron, a multi-factor test was applied to tax regulations to determine whether such regulations permissibly construed a statute. ${ }^{170}$ For almost thirty years after Chevron, deference shown to I.R.S. rulemaking depended on whether the regulations were issued pursuant to a specific statutory grant of authority or pursuant to the general grant of congressional authority under Internal Revenue Code section 7805. ${ }^{171}$ In 2011, in Mayo Foundation for Medical Education \& Research v. United States, the Court no longer predicated the level of deference to which tax regulations were entitled on the source of their authority. ${ }^{172}$ Mayo presented the question whether physicians who serve as medical residents were entitled to a student exemption from certain federal payroll taxes. ${ }^{173}$ The I.R.S. promulgated a regulation pursuant to the general grant of authority under section 7805 that denied medical residents an exemption from the applicable payroll taxes, which the Court upheld the regulation under the Chevron standard. ${ }^{174}$

The Court forcefully rejected the notion that tax regulations are somehow entitled to less deference than the regulatory action of other agencies:

... Mayo has not advanced any justification for applying a less deferential standard of review to Treasury Department regulations than

\footnotetext{
John Roberts, WaLl ST. J., June 26, 2015, at A12.

170. See supra note 69 (discussing the National Muffler test).

171. Id.

172. 562 U.S. 44, 57 (2011).

173. Id. at 52 .

174. Id. at 58-60. See also I.R.C. § 7805(a) (2012).
} 
we apply to the rules of any other agency. In the absence of such justification, we are not inclined to carve out an approach to administrative review good for tax law only. To the contrary, we have expressly "[r]ecogniz[ed] the importance of maintaining a uniform approach to judicial review of administrative action.” .. . Filling gaps in the Internal Revenue Code plainly requires the Treasury Department to make interpretive choices for statutory implementation at least as complex as the ones other agencies must make in administering their statutes.... We see no reason why our review of tax regulations should not be guided by agency expertise pursuant to Chevron to the same extent as our review of other regulations. ${ }^{175}$

The Court refused to apply Chevron to the Treasury regulation that entitled qualified enrollees on Federal Exchanges to tax credits. ${ }^{176}$ According to the Court, Chevron deference is underpinned by the notion that statutory ambiguities carry with them an express or implicit delegation of authority by Congress to the executive branch to resolve such ambiguities. ${ }^{177}$ However, in extraordinary cases, this delegation of authority cannot be assumed. ${ }^{178}$ The Court, citing FDA v. Brown \& Williamson Tobacco Corp., asserted that the issue presented in the case was too central to the functioning of the Patient Protection and Affordable Care Act for Congress to have left it to the I.R.S. to resolve. ${ }^{179}$ Moreover, the Court's assertion was buttressed by the lack of I.R.S. expertise in crafting or enforcing health care policy - an assertion not shared by the Fourth Circuit. ${ }^{180}$

The Court's reasoning for its refusal to apply Chevron in this case is troubling in two respects. First, the importance of an issue should not be used as conclusive evidence of congressional intent on an issue. Instead, a court should consider this factor only if there is no discernable congressional intent with respect to an issue. Second, the Court's introduction of agency expertise as a factor for consideration in resolution of this issue may very well serve to undo much of what Mayo

\footnotetext{
175. Id. at 55-56.

176. See supra notes $116-18$ and accompanying text.

177. Id.

178. Id. The D.C. Circuit has held that the failure of a statute to affirmatively withhold authority from a regulatory agency does not support the presumption that such authority was, in fact, delegated by Congress to a regulatory agency. See Ry. Labor Execs. Ass'n. v. Nat'l Mediation Bd., 29 F.3d 655, 659 (D.C. Cir. 1994); see also Am. Bar Ass'n v. FTC, 430 F.3d 457, 468 (D.C. Cir. 2005).

179. See supra note 119 and accompanying text.

180. See supra notes 69, 119 and accompanying text.
} 
did with respect to the status of Treasury regulations.

The Court has, in effect, used the issue of congressional delegation as part of a feedback loop used to resolve step one of Chevron: if a statute is ambiguous, we then determine if the issue's importance belies congressional delegation of authority and then we determine that there is, in fact, no ambiguity. Consequently, Chevron step two is not invoked. For example, in FDA v. Brown \& Williamson Tobacco Corp. the issue before the Court was whether the FDA had the authority to regulate tobacco products:

Finally, our inquiry into whether Congress has directly spoken to the precise question at issue is shaped, at least in some measure, by the nature of the question presented. Deference under Chevron to an agency's construction of a statute that it administers is premised on the theory that a statute's ambiguity constitutes an implicit delegation from Congress to the agency to fill in the statutory gaps. In extraordinary cases, however, there may be reason to hesitate before concluding that Congress has intended such an implicit delegation. ${ }^{18}$

The nature of the question presented should have no bearing on a court's inquiry into whether Congress has spoken directly to the precise question at issue but should bear only on the determination whether the issue was delegated to an agency to resolve. The above quoted statement can be taken to mean that the courts' level of effort in ascertaining whether Congress has spoken to the issue depends on the nature of the question presented. Alternatively, it could be taken to mean that courts must find that Congress has spoken on the issue if the question presented is of significant importance. Neither meaning is comforting.

The statement quoted above was made after the Court explained in twenty-three pages of its opinion that Congress indeed had foreclosed the FDA from regulating tobacco products. ${ }^{182}$ It should have made no difference that this case was extraordinary. Congress's intent, as the Court exhaustively made evident, was clear. Likewise, after parsing the statute as a whole, the Court came to the conclusion that Congress

181. 529 U.S. 120, 159 (2000). The Court also quoted from a law review article written by Justice Breyer before he was confirmed to the Court. Id. "A court may also ask whether the legal question is an important one. Congress is more likely to have focused upon, and answered, major questions, while leaving interstitial matters to answer themselves in the course of the statute's daily administration." Id. (quoting Stephen Breyer, Judicial Review of Questions of Law and Policy, 38 AdMIN. L. REV. 363, 370 (1986)).

182. Brown \& Williamson Tobacco Corp., 529 U.S. at 133-56. 
intended to make tax credits available to enrollees on Federal Exchanges. At that point, there is no ambiguity and the importance of the issue at hand is irrelevant.

The Court in Chevron determined that an ambiguity existed in the statute and that the EPA's resolution of the ambiguity was a reasonable accommodation of competing policy interests. ${ }^{183}$ The Court then noted that "[i]f this choice represents a reasonable accommodation of conflicting policies that were committed to the agency's care by the statute, we should not disturb it unless it appears from the statute or its legislative history that the accommodation is not one that Congress would have sanctioned." 184 The Court failed to explain how an accommodation that Congress would not have sanctioned could ever be a "reasonable accommodation of conflicting policies that were committed to the agency's care." 185 Either the issue was committed to the agency's care or it was not.

Jonathan Adler and Michael Cannon stated the following in their seminal article that gave prominence to the issue in King v. Burwell:

Suppose, however, the IRS was able to convince a reviewing court that the PPACA is ambiguous on whether it limits tax credits to state-based Exchanges. The IRS would also need to demonstrate that this ambiguity was evidence of an implicit delegation of authority to interpret the statute in a way that would authorize the creation of new tax credits, new entitlement spending, and new taxes on employers and individuals beyond the purview of the traditional legislative appropriations process. This is not the sort of authority one should lightly presume Congress delegated to an agency. To paraphrase the Supreme Court, Congress does not hide such "elephants in mouseholes." 186

If Congress indeed does not hide such "elephants in mouseholes," then I fail to ascertain how the I.R.S. could convince a reviewing court that an ambiguity exists to justify its action. Whether an issue is important is not relevant if Congress intended a particular result.

Under Chevron, a court first must determine whether or not the statute evidences a congressional intent with respect to the matter at

183. Chevron, U.S.A., Inc. v. Nat. Res. Def. Council, 467 U.S. 837, 843 (1984).

184. Id. at 845 (quoting United States v. Shimer, 367 U. S. 374, 382-83 (1961)).

185. Id.

186. Jonathan H. Adler \& Michael F. Cannon, Taxation Without Representation: The Illegal IRS Rule to Expand Tax Credits Under the PPACA, 23 HEALTH Matrix 119, 180 (2013) (quoting Whitman v. Am. Trucking Ass'ns, 531 U.S. 457, 468 (2001)). 
hand. ${ }^{187}$ Clarity of statutory language is, of course, the best evidence of such intent. For example, had section 36B stated that tax credits are available to eligible individuals enrolled on "any Exchange," "an Exchange established by a State or the Federal government," or, conversely, "an Exchange established by a State (but not the Federal government or any instrumentality therefor)" the intent of Congress would have been clearly manifested by the statutory language. In many cases, Congress does not reveal its intent so obviously. Whether or not the statutory language plainly reveals Congress's intent is, of course, subject to debate, and the various axioms of statutory construction exist to assist a court in the revelation of such intent.

King v. Burwell may very well find a place in the casebooks that teach statutory interpretation. The majority, in support of its position, used, by my count, three canons of statutory construction: the words of a statute must be read in context and given their place in the overall statutory scheme; federal statutes cannot be interpreted to negate their own stated purposes; and fundamental details of a regulatory scheme are not altered in vague or ancillary provisions. ${ }^{188}$ The importance of the first canon noted-contextual analysis - to Chief Justice Roberts and Justice Kennedy apparently varies from case-to-case. In the recent case of Burwell v. Hobby Lobby Stores, Inc., ironically another case that involved the Patient Protection and Affordable Care Act, both Chief Justice Roberts and Justice Kennedy placed significant emphasis on the Dictionary Act's definition of "person" in reaching the conclusion that the Religious Freedom Restoration Act was applicable to closely-held corporations. ${ }^{189}$

Not to be outdone, the dissent in King v. Burwell put forth its own set of canons to refute the majority's conclusion: the plain and obvious

187. Prior to Chevron, the courts did give significant weight to administrative agencies' reasonable interpretation of legislation. However, the courts were not consistent in this respect. See Antonin Scalia, Judicial Deference to Administrative Interpretations of Law, 1989 DUKE L.J. 511, 512-13 (1989).

188. See supra notes $120,136,139$ and accompanying texts

189. 134 S. Ct. 2751, 2768-70 (2014). The issue in this case was whether the Religious Freedom Restoration Act was applicable to three closely-held corporations so that the contraception coverage mandate of the Patient Protection and Affordable Care Act was not applicable to such corporations. Id. at 2740. The Court held that the corporations were not subject to the mandate because the imposition of the mandate on such corporations violated the Religious Freedom Restoration Act. See id. at 2759. Ascertaining the meaning of terms by reference to other parts of the law or to the structure of the law as a whole is an approach often useful in ascertaining the meaning of the Constitution. See generally Akhil Reed Amar, Intratextualism, 112 HARV. L. REV. 747 (1999). 
meaning of a statute is preferable to other meanings; it is presumed that lawmakers use words in their natural and ordinary signification; lawmakers do not use terms that have no operation at all; and specific terms govern over general terms. ${ }^{190}$ The enlistment of these tools by both the majority and the dissent was made for one purpose-to answer the question of whether Congress intended for tax credits to be available to enrollees on Federal Exchanges. ${ }^{191}$

Chief Justice Roberts stated that the meaning of the term "established by the State" was ambiguous because such term reasonably could be interpreted in two ways. ${ }^{192}$ He then proceeded to explain why Congress intended for such a term to encompass Federal Exchanges. ${ }^{193}$ At this point, there is no more ambiguity. Chevron requires a court to determine whether the intent of Congress is ambiguous. Ambiguity of language is not the same thing as ambiguity of intent. In addition to the various canons of statutory interpretation, congressional intent can be gleaned from extraneous sources such as other legislation. The Court, in FDA v. Brown \& Williamson Tobacco Corp., exhaustively examined other congressional actions in determining whether Congress intended to provide the FDA with regulatory authority over tobacco. ${ }^{194}$ The importance of the issue to an overall regulatory scheme or to the economy or to some other important matter is but a factor in the courts' inquiry with respect to congressional intent, but an issue's importance should not be treated as de facto evidence that such intent existed. To do so provides the judiciary with an excuse to substitute its policy preferences for those of Congress. After all, Congress may not have intended to delegate an issue to an agency, but it surely did not intend to delegate it to a court.

Ambiguity of statutory language represents either a lack of clarity on the part of the legislature in making its intent known or a lack of intent with respect to the issue at hand. The more critical and central a seeming ambiguity is to a regulatory scheme the more likely it is that the legislature intended a particular result. This is a common-sense

190. King v. Burwell, 135 S. Ct. 2480, 2497-2500 (2014) (Scalia, J., dissenting).

191. It has been suggested that this case also concerned two broader issues-the manner in which legislation is drafted and debated and the appropriateness of increasing the compliance burden on an already overburdened I.R.S. See Armando Gomez, Why Should Tax Lawyers Care About King v. Burwell?, 6 COlum. J. TAX L. TAX MAtTers 4, 5 (2015). Whether or not the Court could have, or should have, considered those issues is beyond the scope of this work.

192. See supra text accompanying note 124; King, 135 S. Ct. at 2491.

193. King, 135 S. Ct. at 2491-95.

194. See 529 U.S. 120, 133-56 (2000). 
assumption. The judiciary is tasked to determine what the law is and, in carrying out this task, the underlying policy or policies furthered by the law is fair game for judicial consideration. The separation of powers justification for Chevron deference does not diminish the courts' role in examining policy but, in fact, supports it. After all, if Congress chose not to delegate authority to the executive branch, then the judiciary should not grant such authority to the executive branch through the Chevron back door. Conversely, if the executive branch has been delegated authority, then the judiciary should not substitute its own policy judgments for the judgment of the branch of government to which Congress deferred.

However, in many circumstances Congress has given no thought at all to the matter for one of two reasons. First, the matter either is one of implementation or is one that implicates the application of a rule to one of many possible fact patterns potentially covered by the rule that Congress passed off to an agency. It is precisely these situations that justify Chevron deference. The regulatory agencies have the policy and technical expertise to deal with such situations. Perhaps more importantly, the agencies are politically accountable through the elected executive branch officials, provide constituent participation through notice and comment procedures, ${ }^{195}$ and have the flexibility to alter their positions as circumstances warrant.

Second, Congress never contemplated the issue at all, and the importance of the issue raised makes it doubtful that Congress intended to leave the issue for the agency to resolve. It is quite possible that social, technological, or other developments present a fact pattern that the legislature could have not foreseen. I concur with the Court that Chevron deference should not apply to these situations. However, in such situations, the Court should not substitute its own policy preferences in the guise of a congressional intent that did not exist. In such cases, the courts should not enforce the regulations in question and leave the matter to Congress.

Whether an issue's importance negates or implies congressional delegation will itself be a difficult issue. One would think that King $v$. Burwell was an easy case in this respect. Not all disputes will be so obvious and so obviously important. Whether enrollees on Federal

195. Chevron is applicable only to tax regulations issued with notice and comment. Informal guidance, such as Revenue Rulings, are subject to a less deferential standard. Positions advanced for the purposes of litigation and not previously published are also subject to a less deferential standard. See supra note 69; see also Bowen v. Georgetown Univ. Hosp., 488 U.S. 204, 213 (1988). 
Exchanges qualify for tax credits is critical to the operation of the health care reform sought by the legislation, is not an obscure issue, and is not an issue that arose from a set of facts not contemplated by Congress. Precisely what Congress intended in this respect is subject to debate-as evidenced by the vigorous dissent in this case, but it is difficult to dispute the far-reaching consequences of the resolution of this dispute. Yet, in contrast to the Court, the Fourth Circuit believed that the very importance of the issue implied that Congress delegated its resolution to the I.R.S. ${ }^{196}$ The fact that two courts drew opposite conclusions with respect to whether there was an implicit delegation of authority in this case illustrates the difficulty of ascertaining just what Congress had in mind.

For example, let us suppose that the phrase "established by the State but not by the federal government or any instrumentality thereof" replaced the language presently found in section $36 \mathrm{~B}$ and that the statute and legislative history made no mention of the possibility that states and the federal government could partner to operate an Exchange. Suppose further that the Treasury Department issued regulations that defined an Exchange "established by the State but not by the federal government or any instrumentality thereof" to include Exchanges that were operated by states in partnership with the Department of Health and Human Services. ${ }^{197}$ This regulation would satisfy both the policy goal of insurance affordability and the policy goal of state participation. In the event Congress contemplated that states would either form an Exchange or would not participate at all, the possibility of partial participation by a state in operating an Exchange would not have occurred to Congress at the time the legislation was deliberated and enacted. However, the importance of this issue to the overall statutory scheme would be significant if a great number of states chose to partner with the Department of Health and Human Services. Whether it is of such import to negate the implication that Congress intended the Treasury Department to deal with such a development is unclear. If it did, then Chevron deference should accrue to the regulation in question. If not, then the Court should not fabricate a congressional intent when none existed, and it should strike down the regulation.

A troubling aspect of the majority opinion was the question of the I.R.S.'s expertise. Chief Justice Roberts remarked that congressional

196. See King v. Burwell, 759 F.3d 358, 373 n.4 (4th Cir. 2014), aff'd, 135 S. Ct. 2480 (2015).

197. See supra note 18 and accompanying text. 
delegation of a matter so central to the operation of health insurance reform as the qualification for tax subsidies was unlikely. ${ }^{198}$ He went on to state that the delegation of such a matter to the I.R.S. was even more unlikely given its lack of expertise in health care policy. ${ }^{199}$ This statement - perhaps intended for effect — could undermine the equipoise that Mayo provided between the I.R.S. and other federal agencies. ${ }^{200}$ Agency expertise is one factor that supports Chevron deference-a factor that is, perhaps, all the more justified in an increasingly complex society. ${ }^{201}$ Justice Ginsburg recently stated that " $[\mathrm{t}]$ he expert agency is surely better equipped to do the job than individual district judges issuing ad hoc, case-by-case injunctions. Federal judges lack the scientific, economic, and technological resources an agency can utilize in coping with issues of this order.",202

However, tax legislation often is enacted to serve policy goals unrelated to revenue collection. For example, housing, education, health care, and retirement security policy goals are served, in part, through the tax system. ${ }^{203}$ Will the I.R.S.'s lack of expertise in these areas somehow subject its regulations to greater scrutiny? Does the fact that Congress expressly delegated regulatory authority to the I.R.S. in these areas inhibit the courts from considering this issue, or will the courts heighten their efforts to find the issue at hand too important to have been part of that express delegation? After all, section 36B did contain an express grant of regulatory authority that the Court found could not have encompassed the authority to determine who is eligible for tax credits. ${ }^{204}$ Arguably, the Court now has resorted to second-guessing the wisdom of Congress not for its delegation of authority, but for its choice of agency to which such authority was delegated. ${ }^{205}$

\footnotetext{
198. See supra text accompanying note 119 .

199. Id.

200. See supra note 69 and accompanying text.

201. See Chevron, U.S.A., Inc. v. Nat. Res. Def. Council, Inc., 467 U.S. 837, 844, 865 (1984).

202. Am. Elec. Power Co. v. Connecticut, 131 S. Ct. 2527, 2539-40 (2011).

203. See, e.g., I.R.C. § 25A (2012) (providing a credit for certain educational expenses); Id. § 36 (providing a credit for first time homebuyers); Id. § 105 (providing an exclusion for employer provided medical insurance); $I d$. $\S 213$ (providing a deduction for medical and dental expenses); $I d$. $\S \S 401-09$ (providing tax deferred retirement vehicles).

204. See supra notes $69,117-19$ and accompanying text.

205. Perhaps the Patient Protection and Affordable Care Act prompts the Court to slight the separation of powers. As noted at supra note 41, Burwell v. Hobby Lobby Stores, Inc. involved the application of the Religious Freedom Restoration Act to three closely-held corporations whose shareholders objected, on religious grounds, to the provision of certain contraceptive services mandated by the Patient Protection and Affordable Care Act. 134 S. Ct. 2751, 2755 (2014). Under
} 


\section{Illustrative Examples}

Two relatively recent tax issues illustrate the application of Chevron to situations that Congress, most likely, did not contemplate. The first example, relating to the nuances of the mortgage interest deduction, is unlikely and extraordinary. The second example deals with the application of the gift tax to contributions to social welfare organizations to support political activity. This issue may very well be deemed extraordinary.

\section{a. Mortgage Interest Deduction}

In general, taxpayers, other than corporations, may not deduct personal interest paid or accrued during the taxable year. ${ }^{206}$ However, excluded from the definition of personal interest is qualified residence interest. ${ }^{207}$ Qualified residence interest is defined as interest that is paid or accrued during the taxable year either on "acquisition indebtedness with respect to any qualified residence of the taxpayer" or on "home equity indebtedness with respect to any qualified residence of the taxpayer." ${ }^{208}$ The amount of acquisition indebtedness and home equity indebtedness is limited to $\$ 1,000,000$ and $\$ 100,000$, respectively. ${ }^{209}$ For

the Religious Freedom Restoration Act, federal government action that substantially burdens the exercise of person's religion must be justified by a compelling government interest and provide the least restrictive means of achieving this interest. See 42 U.S.C. § 2000bb-1(b) (2012). The Court believed that direct government payment for the disputed services was a least restrictive means of achieving the objectives of the contraception mandate. Hobby Lobby Stores, Inc., 134 S. Ct. at 2780. "The most straightforward way of doing this would be for the Government to assume the cost of providing the four contraceptives at issue to any women who are unable to obtain them under their health-insurance policies due to their employers' religious objections." Id. The Department of Health \& Human Services did not produce statistics to refute the Court's assumption that the cost of such coverage to the government would be minor. Id. at 2780-81. This was a bold pronouncement by the Court because the same can be said of various government benefits. This reasoning would require that, for any program not expressly exempted from Religious Freedom Restoration Act's requirements, the government either must anticipate religious objections and score the cost of providing direct government funding or be prepared to do so in litigation. Moreover, the short-term costs of government funding do not take into account dynamic factors such as the effect that modifications to existing programs will have on market prices and on the behavior of the market participants - factors often beyond the predictive ability of the administrative agencies with specialized expertise in the area in question let alone a court.

206. I.R.C. § 163(h)(1).

207. Id. $\S 163(\mathrm{~h})(2)(\mathrm{D})$.

208. Id. § 163(h)(3). A qualified residence is the taxpayer's principal residence, as defined in section 121, and one other residence, as defined in section $280 \mathrm{~A}(\mathrm{~d})(1)$, selected by the taxpayer. Id. $\S 163(\mathrm{~h})(4)(\mathrm{A})(\mathrm{i})$.

209. The statutory definitions of acquisition indebtedness and home equity indebtedness and the limitations thereon are as follows: 
married individuals that file separate returns, the aforementioned dollar limitations are halved. ${ }^{210}$

A relatively recent Tax Court case, Sophy v. Commissioner, ${ }^{211}$ dealt with the issue of whether the limitations on the amount of debt the interest on which qualifies for the mortgage interest deduction apply on a per-residence or per-taxpayer basis. Charles Sophy and his domestic partner each deducted an amount of interest on their individual tax returns that was determined under the assumption that the dollar limitations on the amounts of acquisition indebtedness and home equity indebtedness were available to each in full. In the aggregate, the debt on which the interest deductions were based exceeded the statutory dollar limits. Consistent with informal guidance that it previously issued, the I.R.S. asserted that the dollar limitations on acquisition and home equity indebtedness are applicable on a per-residence basis and not a pertaxpayer basis. ${ }^{212}$ The Tax Court, based on statutory construction, held for the I.R.S. and applied the limitations on a per-residence basis. ${ }^{213}$

Section 163(h)(3)(B) Acquisition indebtedness.

(i) In general. The term "acquisition indebtedness" means any indebtedness which-

(I) is incurred in acquiring, constructing, or substantially improving any qualified residence of the taxpayer, and

(II) is secured by such residence. Such term also includes any indebtedness secured by such residence resulting from the refinancing of indebtedness meeting the requirements of the preceding sentence (or this sentence); but only to the extent the amount of the indebtedness resulting from such refinancing does not exceed the amount of the refinanced indebtedness.

(ii) $\$ 1,000,000$ limitation. The aggregate amount treated as acquisition indebtedness for any period shall not exceed $\$ 1,000,000$ ( $\$ 500,000$ in the case of a married individual filing a separate return).

Section 163(h)(3)(C) Home equity indebtedness.

(i) In general. The term "home equity indebtedness" means any indebtedness (other than acquisition indebtedness) secured by a qualified residence to the extent the aggregate amount of such indebtedness does not exceed-

(I) the fair market value of such qualified residence, reduced by

(II) the amount of acquisition indebtedness with respect to such residence.

(ii) Limitation. The aggregate amount treated as home equity indebtedness for any period shall not exceed $\$ 100,000$ ( $\$ 50,000$ in the case of a separate return by a married individual).

Id. $\S \S 163(\mathrm{~h})(3)(\mathrm{B})(\mathrm{ii}),(\mathrm{h})(3)(\mathrm{C})(\mathrm{ii})$.

210. Id.

211. 138 T.C. 204, 209 (2012). The Ninth Circuit reversed the Tax Court. Voss v. Comm'r, 796 F.3d 1051 (9th Cir. 2015); see infra note 214.

212. Sophy, 138 T.C. at 212. On March 13, 2009, the I.R.S. released Chief Counsel Advice Memoranda 2009-11-007 in which it took the position that the \$1,000,000 limitation on acquisition indebtedness is applied on a per-residence basis and not on a per-taxpayer basis. I.R.S. Chief Counsel Advice Mem., IRS CCA 200911007 (Nov. 24, 2008).

213. According to the court, the possessive phrases "of the taxpayer" in both the definitions of 
An equally plausible reading of the statute leads to the opposite conclusion than that reached by the Tax Court. Section 163(h)(3)(B)(i) states that " $[\mathrm{t}]$ he term 'acquisition indebtedness' means any indebtedness which is incurred in acquiring, constructing, or substantially improving any qualified residence of the taxpayer and is secured by such residence." 214 Each party incurred debt to acquire a qualified residence, and each party's debt was secured by such residence. ${ }^{215}$ The definitional provisions are applied on a per taxpayer basis. Whether a debt meets the statutory definition is determined by whether the taxpayer incurred the debt to acquire, construct, or substantially improve a property whose use by the taxpayer qualifies the debt under the statute. For example, a cotenancy could involve the use of the house by one co-tenant as a principal residence and the use by the other co-tenant as an investment. In such circumstances, whether the debt to acquire the property qualifies as acquisition indebtedness under $\S 163(\mathrm{~h})(2)(\mathrm{D})$ is determined by each taxpayer individually.

Section 163(h)(3)(B)(ii), the limitation provision, is just that - a limitation provision. As a limiting provision, it merely establishes a limit that is applied to debt that otherwise meets the requirements of the definitional section. The Tax Court's interpretation of the statute inserts a substantive provision - an aggregate limit on the total debt secured by the residence — within the limitation provision. Finally, the reduced debt

acquisition indebtedness and home equity indebtedness refer to the residence and not the debt. Sophy, 138 T.C. at 212 . Thus, the reference "of the taxpayer" in the phrase that defines acquisition indebtedness as any debt "incurred in acquiring, constructing, or substantially improving any qualified residence of the taxpayer" should be interpreted not to refer to the debt of the taxpayer but to the residence of the taxpayer. Id. at 208, 210, 211 (emphasis added). The court believed that the statute's reference to "any debt" is not qualified by any language relating to a particular taxpayer. Id. at 210. Therefore, the dollar limitations on acquisition indebtedness and home equity indebtedness should be interpreted to limit the total amount of debt with respect to a particular residence and not the total amount of debt incurred by a particular taxpayer. Id. at 211. The court opined that the repeated references to "the taxpayer" throughout $\S 163(\mathrm{~h})$ but its conspicuous absence in the debt limitation provisions was evidence that Congress did not intend the limitations to be applied on a per-taxpayer basis. Id. The court also found support for its position in the parenthetical language of $\S 163(\mathrm{~h})(3)(\mathrm{B})(\mathrm{ii})$ and $\S 163(\mathrm{~h})(3)(\mathrm{C})(\mathrm{ii})$ which halve the limitations for married taxpayers that file separate returns. Id. at 212. This language implies that married couples that file a joint return are subject to the $\$ 1,100,000$ limitation as a couple. Id. The court dismissed the argument that the limitations imposed on married couples that file separate returns are a form of "marriage penalty." Id. at 212-13. Instead, the court interpreted these limitations as a mandatory allocation of the total limitations among spouses that file separate tax returns. Id. at 213.

214. I.R.C. $\S 163(\mathrm{~h})(3)(\mathrm{B})(\mathrm{i})(\mathrm{I})-(\mathrm{II})$. Similar language applies to home equity indebtedness. For the sake of simplicity, the discussion is limited to acquisition indebtedness. The Ninth Circuit believed that this interpretation of the statute was correct and recently reversed the Tax Court. See Voss v. Comm'r, 796 F.3d 1051, 1053 (9th Cir. 2015).

215. Sophy, 138 T.C. at 205. 
limits on married couples that file separate returns can be interpreted to imply that a married couple that does file a joint return is treated as one taxpayer, and this provision places married couples not so filing on the same footing. If so, then the reason that married couples that file jointly are limited in the aggregate to the debt limitations is not because the limitations are determined on a per-residence basis but because joint filers are treated as one taxpayer.

\section{b. Gift Tax and Social Welfare Organizations}

A federal gift tax is imposed for each calendar year on the transfer of property by gift by any individual during such calendar year. ${ }^{216}$ The gift tax, introduced by the Revenue Act of 1924, supplements the federal estate tax, and it prevents individuals from avoiding the imposition of a wealth transfer tax through lifetime transfers. ${ }^{217}$ Among the various transfers that are either exempt from the gift tax or are deductible in arriving at the total of taxable gifts are transfers of money or property to section 527 political organizations. ${ }^{218}$ This exception, effective for transfers made after May 7, 1974, was enacted in $1975 .^{219}$

Neither an exemption nor a deduction is provided for gifts made to

216. I.R.C. $\S 2501(\mathrm{a})(1)$. The gift tax is imposed on the donor. Id. $\S 2502$ (c).

217. See Burnet v. Guggenheim, 288 U.S. 280, 282, 286 (1933). The constitutionality of wealth transfer taxes was settled long ago. See Scholey v. Rew, 90 U.S. 331, 349-50 (1875); Knowlton v. Moore, 178 U.S. 41, 81-82 (1900); Bromley v. McCaughn, 280 U.S. 124, 137-38 (1929). The gift tax was repealed in 1926 but reenacted in 1932 with the passage of the Revenue Act of 1932, Pub. L. No. 72-154, § 501, 47 Stat 169, 245 (1932). A unified credit against the donor's tax liability is provided. I.R.C. $\S \S 2010,2505$. The credit is a statutory amount, adjusted annually for inflation, which is available to offset lifetime gift tax or testamentary estate tax liability. Id. Effective in 2015, the unified credit will shelter tax liability on cumulative lifetime and testamentary transfers up to $\$ 5,430,000$. See Rev. Proc. 2014-61, § 3.33, 2014-47 I.R.B. 860. The unified credit has been made permanently portable among spouses. See id. § 2010(c)(4). A surviving spouse, absent an election to the contrary by the executor of the deceased, automatically succeeds to any unused unified credit of the deceased spouse. $I d$. Therefore, an individual conceivably could shelter up to $\$ 10,860,000$ of asset transfers from gift and estate tax liability. See id.

218. I.R.C. $§ 2501(a)(4)$. These organizations are parties, committees, associations, funds, or other incorporated or unincorporated organizations that are organized and operated for the purpose of accepting contributions and making expenditures to influence, or attempt to influence, the selection, nomination, election, or appointment of any individual to any Federal, State, or local public office or office in a political organization, or the election of Presidential or Vice-Presidential electors. Id. § 527(e)(1)-(2).

219. Pub. L. No. 93-625, § 14, 88 Stat. 2108, 2121 (1975) (codified as amended at I.R.C. § 2501(a)(5)). Several other transfers are not included in the taxable gift total for the taxable year. Annual gifts of $\$ 14,000$ per donee are not considered gifts made during the taxable year. See I.R.C. $\S 2503$ (b)(1); Rev. Proc. 2014-61, § 3.35(1), 2014-47 I.R.B. 860. Various other transfers are not deemed gifts or are deductible in arriving at the total of taxable gifts. See I.R.C. §§ 2503(e), 2503(g), 2516, 2518, 2522, 2523. 
section 501(c)(4) organizations. These organizations are a form of taxexempt organization operated exclusively for the promotion of social welfare. ${ }^{220}$ Section 501(c)(4) organizations may engage in political campaigns provided that such activity does not constitute the organization's primary activity. ${ }^{221}$ These organizations have become increasingly important players in political campaigns because they are not subject to the reporting and disclosure requirements imposed on section 527 organizations.

Congress failed to define the term "gift," and Treasury regulations define the term expansively. For gift tax purposes, gifts are not limited to transfers of property made with detached and disinterested generosity, and donative intent on the part of the transferor is not an essential element in the application of the tax. ${ }^{222}$ Moreover, if the consideration received in a transaction cannot be reduced to a value in money or money's worth, such as love or affection, then such consideration is to be wholly disregarded and the transaction considered a gift in its entirety. ${ }^{223}$ However, a sale or exchange, or other transfer of property made in the ordinary course of business is deemed to have been made for adequate and full consideration in money or money's worth. ${ }^{224}$ The Supreme Court noted that "Congress intended to use the term 'gifts' in its broadest and most comprehensive sense ... to hit all the protean arrangements which the wit of man can devise that are not business transactions within

220. I.R.C. $\$ 501(\mathrm{c})(4)(\mathrm{A})$.

221. A $\S 501(c)(4)$ organization "is operated exclusively for the promotion of social welfare if it is primarily engaged in promoting in some way the common good and general welfare of the people of the community." Treas. Reg. $§ 1.501(c)(4)-1(a)(2)(i)$ (2012) (emphasis added). Proposed regulations were issued that would expand the types of activities that cannot be within the scope of an organization's primary activities. Prop. Treas. Reg. § 1.501(c)(4)-1(a)(2)(ii), 78 Fed. Reg. 71535 (Nov. 29, 2013). The preamble to the proposed rules indicates that the ability of these organizations to engage in political activity provided that such activity is not their primary activity is also under review. See id.

222. Treas. Reg. $\$ 25.2511-1$ (g)(1) (as amended in 1997).

223. Id. See also Wiedemann v. Comm'r, 26 T.C. 565, 570 (1956) (holding that payments to support an adult child were gifts); Rev. Rul. 79-384, 1979-2 C.B. 344 (ruling that a payment in satisfaction of a promise to graduate from college was a gift).

224. Treas. Reg. $\$ 25.2512-8$ (1992). The courts have held that the ordinary course of business exception applies to transactions for which the transferor lacked donative intent despite the fact that the transaction in question was not a business transaction in any conventional sense. See, e.g., Harris v. Comm'r, 340 U.S. 106, 112 (1950); see also Rev. Rul. 68-558, 1968-2 C.B. 415 (ruling that the sale of land at a below market price by a group of individuals to a corporation in order to induce the transferee to operate a manufacturing facility in the community was not a gift). The Tax Court, on several occasions, has stated that a bona-fide transfer at arm's length and free of donative intent qualifies for the ordinary business exception regardless of whether the transaction is a business transaction. See, e.g., Estate of Cullison v. Comm'r, 75 T.C.M. (CCH) 2490 (1998); Estate of Berkman v. Comm'r, 38 T.C.M. (CCH) 183 (1979). 
the meaning of ordinary speech." 225 The Court also stated "absent an express exclusion from its provisions, any transfer meeting the statutory requirements must be held subject to the gift tax."226

The sparse case law with respect to the application of the gift tax to political contributions prior to 1975 is marked by inconsistency. ${ }^{227}$ In Stern v. United States, the district court held that political contributions were made in return for full and adequate consideration, and thus were not gifts, because the taxpayer was not motivated by "affection, respect, admiration, charity, or like impulses" but instead made the contributions to promote efficiency in government and to protect her property interests. ${ }^{228}$

In Carson v. Commissioner, the Tax Court held that political contributions made by the petitioners to various candidates for state and local offices were not gifts. ${ }^{229}$ However, the Tax Court's holding went beyond the application of the ordinary course of business exception and held that the gift tax never was intended to encompass political contributions. $^{230}$ This case, according to the court, presented circumstances in which a literal reading of a statute was "at war with its purpose and history." 231 In the court's opinion, the legislative history of the gift tax reenactment in 1932 evidenced that Congress contemplated cases that, "despite the literal words of the statute and considering all the facts and circumstances, were simply transfers foreign to the purpose of the statute." 232

In contrast, in Dupont v. United States, a federal district court held that a contribution to a New York corporation formed to preserve private enterprise, private property, private initiative, and American independence was taxable for gift tax purposes. ${ }^{233}$ The taxpayer asserted

225. Comm'r v. Wemyss, 324 U.S. 303, 306 (1945); see also Wells Fargo Bank N.M., N.A., v. United States, 319 F.3d 1222, 1226 (10th Cir. 2003).

226. Dickman v. Comm'r, 465 U.S. 330, 334 n.4 (1984).

227. The statutory exclusion for transfers to political organizations was enacted in 1975. See supra note 218 and accompanying text.

228. 304 F. Supp. 376, 378-80 (E.D. La. 1969) aff'd. 436 F.2d 1327, 1330 (5th Cir. 1971).

229. 71 T.C. 252, 263-64 (1978) aff'd. 641 F.2d 864 (10th Cir. 1981).

230. Id. at 257. The nature of political contributions belies their categorization as gifts because such contributions are intended to advance a campaign and not to personally benefit a candidate, particularly those candidates who were not the natural objects of the donors' bounty. Id. at 257, 259 .

The contributions were made to "promote the social framework... [and] social structure most conducive to his economic aspirations ...." Id. at 258.

231. Id. at 262-63 (citing to H.R. REP. No. 72-708, at 502 (1932)).

232. Id. at 263 (citing to H.R. REP. No. 72-708, at 502 (1932)).

233. 97 F. Supp. 944,946 (D. Del. 1951). 
the contribution was not a gift but a payment for services to be rendered by experts in monetary, business, and political conditions in the United States and elsewhere. ${ }^{234}$ The court disagreed with the taxpayer's categorization of the payment and emphasized that the consideration claimed by the taxpayer in exchange for the payment was not reducible to money's worth. ${ }^{235}$ The fact that any benefit derived by the taxpayer from the payment was enjoyed not only by the taxpayer but also by every citizen in the country made such contributions akin to the transfer of funds to a political party that shared his economic views or to a journal that shaped public opinion. ${ }^{236}$

In a 1959 ruling, the I.R.S. took the position that contributions to political parties or candidates were subject to gift tax. ${ }^{237}$ The I.R.S. later reiterated its position when it announced that it would follow Stern only in the Fifth Circuit and that contributions to political parties cannot be treated as made to various candidates for purposes of applying the gift tax annual exclusion. ${ }^{238}$ In 1982, the I.R.S. stated that it would no longer contend that contributions made to political organizations described in section 527 prior to May 8, 1974, were subject to gift tax. ${ }^{239}$ However, the I.R.S. made clear its position that gratuitous transfers to organizations not described in section 527 are subject to gift tax regardless of whether such contributions are motivated to advance the donor's social, political, or charitable objectives. ${ }^{240}$ This issue remained dormant until the run-up to the 2012 election, at which time the I.R.S. resurrected it temporarily. ${ }^{241}$

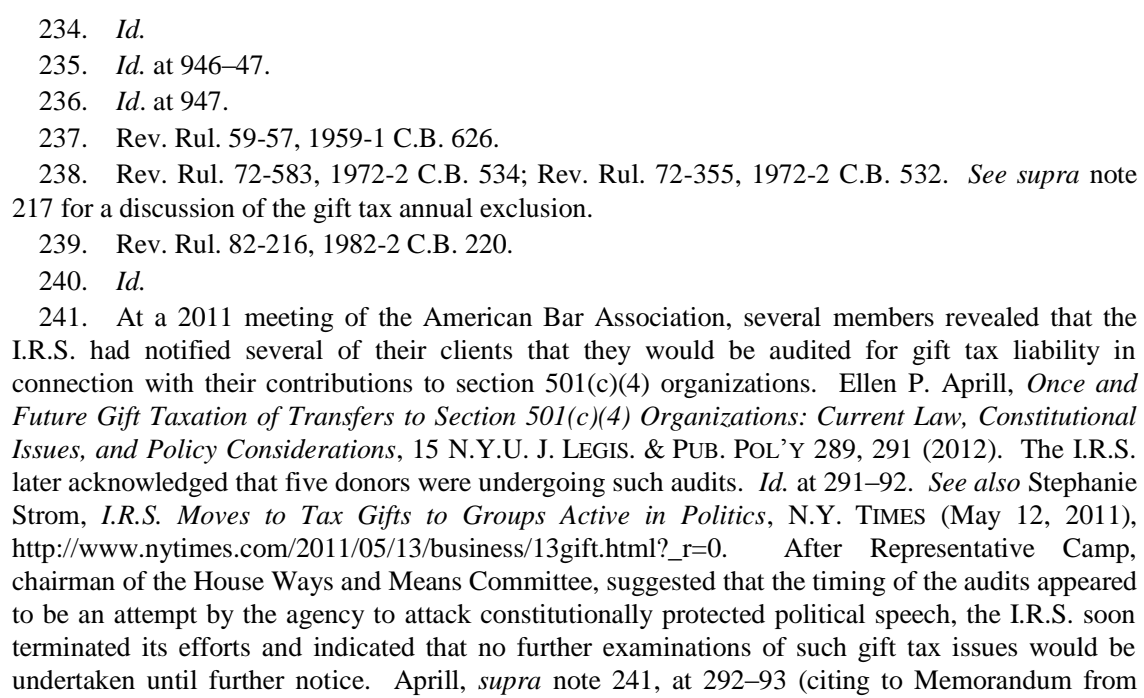

241. At a 2011 meeting of the American Bar Association, several members revealed that the I.R.S. had notified several of their clients that they would be audited for gift tax liability in connection with their contributions to section 501(c)(4) organizations. Ellen P. Aprill, Once and Future Gift Taxation of Transfers to Section 501(c)(4) Organizations: Current Law, Constitutional Issues, and Policy Considerations, 15 N.Y.U. J. LEgIS. \& PUB. POL'Y 289, 291 (2012). The I.R.S. later acknowledged that five donors were undergoing such audits. Id. at 291-92. See also Stephanie Strom, I.R.S. Moves to Tax Gifts to Groups Active in Politics, N.Y. TimeS (May 12, 2011), http://www.nytimes.com/2011/05/13/business/13gift.html?_r=0. After Representative Camp, chairman of the House Ways and Means Committee, suggested that the timing of the audits appeared to be an attempt by the agency to attack constitutionally protected political speech, the I.R.S. soon terminated its efforts and indicated that no further examinations of such gift tax issues would be undertaken until further notice. Aprill, supra note 241, at 292-93 (citing to Memorandum from 
The campaign finance landscape has changed significantly since 1975 as a result of both legislative changes and Supreme Court decisions. In the seminal case of Buckley v. Valeo, the Supreme Court held that the regulation of political expenditures could reach only coordinated expenditures or expenditures that funded express advocacy. ${ }^{242}$ This holding opened the door to increased issue advocacy expenditures by political parties-so-called soft money. ${ }^{243}$ However, the passage of the McCain-Feingold Act in 2002 resulted in the prohibition of the use of soft money by political parties. ${ }^{244}$ As a result, section 527 organizations increased in prominence.

After Buckley, only political organizations that engage in express advocacy or that coordinate their activities with a candidate, candidate's committee, or political party are subject to regulation by the Federal Election Commission (F.E.C.). ${ }^{245}$ Many activities of section 527 organizations do not amount to express advocacy and, accordingly, are outside the scope of the campaign finance rules. ${ }^{246}$ However, all section 527 organizations are subject to disclosure requirements, similar to those required under the campaign finance rules administered by the I.R.S. ${ }^{247}$

Campaign practices underwent a sea change as a result of the Court's landmark decision in Citizens United v. FEC. ${ }^{248}$ A far-reaching effect of Citizens United was its refusal to sanction statutory restrictions on

Steven T. Miller, Deputy Comm'r for Servs. \& Enf't, Internal Revenue Serv. (July 7, 2011) (available at IRS Suspends Exams on Application of Gift Tax to Contributions Made to Some Exempt Orgs, 2011 TAX NOTES TODAY 131-18 (2011)); see also AM. BAR Ass'N, COMMENTS OF THE INDIVIDUAL MEMBERS OF THE ABA EXEMPT ORganizATIONS, COMMITTEE'S TASK FORCE ON SECTION 501(C)(4) AND POlitics $13 \quad$ (May 25, 2004), http://www.abanet.org/tax/pubpolicy/2004/040525exo.pdf (noting that there was no evidence of I.R.S. enforcement of the gift tax on donations to $\$ 501(\mathrm{c})(4)$ entities for at least a decade).

242. 424 U.S. 1, 44 (1976).

243. The F.E.C.'s approval of a soft money advertisement by the Republican National Committee that discussed issues but also criticized President Clinton by name fueled the practice of issue advertising and both major parties undertook multi-million dollar issue advertising campaigns during the 1996 election cycle. See Richard Briffault, Symposium, The Political Parties and Campaign Finance Reform, 100 Colum. L. REv. 620, 632 (2000) (citing to F.E.C. Advisory Opinion 1995-25 (1995)).

244. The Bipartisan Campaign Reform Act of 2002 (The McCain-Feingold Act), Pub. L. No. 107-155, §101(a), 116 Stat. 81, 82 (2002) (codified at 52 U.S.C. $\$ 30125$ (2012)).

245. See supra notes $237-38$ and accompanying text.

246. The tax law "encompasses activities that, directly or indirectly, relate to and support any aspect of the process of influencing or attempting to influence" the electoral process. Miriam Galston, Symposium, Emerging Constitutional Paradigms and Justifications for Campaign Finance Regulation: The Case of 527 Groups, 95 GEO. L.J. 1181, 1192 (2007).

247. I.R.C. §527(j) (2012).

248. See 558 U.S. $310(2010)$. 
independent express advocacy expenditures, corporate or otherwise. ${ }^{249}$ Thus, the ability to regulate expenditures was no longer dependent, as it had been since Buckley, on whether expenditures funded either express advocacy or, alternatively, were coordinated. Instead, regulatory power is now dependent upon whether or not the expenditures in question are independent. On March 26, 2010, the Court of Appeals for the D.C. Circuit held in SpeechNow.org. v. FEC that Citizens United compelled it to strike down the contribution limitations imposed on donors to a section 527 organization that fell under the definition of a political committee. $^{250}$ The court reasoned that the constitutional protection afforded by Citizens United to independent political expenditures, including express advocacy expenditures, extends to contributions to organizations that make such expenditures. ${ }^{251}$ As a result, the Super PAC, the colloquial term for a political committee that may receive and spend unlimited amounts for independent expenditures, was born. Although issue-advocacy section 527 organizations are not considered political committees for purposes of the campaign finance law, they are subject to the tax code's reporting and disclosure requirements. ${ }^{252}$ Enter social welfare organizations into the political fray. ${ }^{253}$

Statutory support exists for the position that contributions to section 501(c)(4) organizations are taxable. Section 2501(a)(1) imposes a tax on transfers of property by gift, and, absent a statutory exclusion or deduction, any transfer by gift is subject to tax. Congress provided a deduction for gifts to most section 501(c)(3) organizations and several other types of organizations. ${ }^{254}$ Congress's silence with respect to

\footnotetext{
249. See id. at 360,365 .

250. 599 F.3d 686, 698 (D.C. Cir. 2010).

251. Id. at 694 .

252. See supra note 247 and accompanying text.

253. The political activities of the non-profit sector caught the attention of the I.R.S. as early as 1995, and the Wall Street Journal saw fit to highlight the extent of such political activities in 1997. See Rep. to the Ranking Member Sen. James M. Inhoffe, U.S. Sen. EnV'T \& Pub. Works COMm., Political Activity of ENVIRONMENTAl Groups AND Their SupPorting Foundations, UPDATE 20082 (Sept. 2008). However, the ability to engage in and finance express advocacy as a result of Citizens United and SpeechNow has increased the prominence of such organizations in electoral politics. See generally Citizens United, 558 U.S. at 310; SpeechNow.org, 599 F.3d at 686. It is not uncommon for $\S 527$ Super PACs to be affiliated with $\S 501(c)(4)$ social welfare organizations. For example, President George W. Bush's advisor Karl Rove was instrumental in the formation of American Crossroads, a Super PAC, and its affiliated social welfare organization, Crossroads GPS. See Andrew C. Byrnes \& Cortlin H. Lannin, I Went Down to the Crossroads: Lifting the Blindfold About the Origin of 501(c)(4) Political Advertisements, 46 U.S.F. L. REV. 481, 500-05 (2011).
}

254. I.R.C. § 2522(2)-(4) (2012). 
donations to section 501(c)(4) organizations, in combination with its special treatment of contributions to section 527, section 501(c)(3), and certain other organizations, can be interpreted, under the principle of expressio unius est exclusio alterius, to subject donations to section 501(c)(4) organizations to tax. ${ }^{255}$ Moreover, Congress had plenty of notice of the I.R.S.'s position on this issue, and it failed to codify an exception for transfers to section 501(c)(4) organizations. The tax code disfavors political contributions in many respects, and the imposition of a gift tax on such contributions would not be out of character for Congress. ${ }^{256}$ Finally, many transfers that do not contribute to family wealth accumulation are taxable-gifts to non-relatives, for example. ${ }^{257}$ If the purpose of wealth transfer taxes was solely to prevent family accumulations of wealth, then Congress could have limited their application to transfers that advanced that purpose. Wealth taxes also raise revenue and that objective should not be overlooked.

Several arguments support an exemption for contributions to section 501(c)(4) organizations. First, the codification of an exception for donations to section 527 political organizations can be interpreted as Congress making explicit what had already been implied and not as a change in the law. Moreover, the limitation of the statutory exclusion to donations to section 527 political organizations reflected the practices of the times - section 501(c)(4) organizations would not play a significant political role for more than three decades. ${ }^{258}$ Additionally, the legislative history of the gift tax exemption for contributions to political

255. Expressio unius est exclusio alterius is a maxim of statutory interpretation that means that the expression of one thing is the exclusion of another. BLACK's LAW DICTIONARY 521 (5th ed. 1979). See e.g., Cipollone v. Liggett Grp., Inc., 505 U.S. 504, 517 (1992) (supporting preemption of state law on "a variant of the familiar principle of expressio unius est exclusio alterius: Congress' enactment of a provision defining the pre-emptive reach of a statute implies that matters beyond that reach are not pre-empted").

256. For example, no deduction is allowed for amounts paid or incurred in "(A) influencing legislation, (B) participation in, or intervention in, any political campaign ..., (C) any attempt to influence the general public, or segments thereof, with respect to elections, legislative matters, or referendums, or (D) any direct communication with a covered executive branch official . ..." I.R.C. $\S 162(\mathrm{e})(1)$. Moreover, dues paid to certain tax-exempt organizations that are allocable to such activities are similarly non-deductible. $I d$. $\$ 162(\mathrm{e})(3)$. Deductions for certain indirect contributions to political parties, such as advertising in convention programs and other publications and admission costs to dinners and inaugural events are also not deductible. Id. § 276(a). Except for banks, taxpayers are prohibited from taking bad deductions or losses from worthlessness of debts owed by political parties. Id. $\S 271$.

257. No exception applies for gifts made to non-family members. See id. $\$ \S 2501 ; 2503 ; 2511$; see also id. $\$ 2513$ (a) (stating that gifts made to any person other than a spouse are treated as made one-half by each spouse if certain requirements are met).

258. See supra notes 237-47 and accompanying text. 
organizations indicates that Congress did not want the tax system to discourage political contributions and that the application of the tax to donations to section 501(c)(4) organizations is at odds with congressional intent. ${ }^{259}$

Let us assume that Treasury regulations are issued that apply a per residence limitation on the mortgage interest deduction and subject contributions to social welfare organizations to the gift tax. Are either, neither, or both of these regulations entitled to Chevron deference? Perhaps the Tax Court's interpretation of the interest deduction provision in Sophy is the correct one and perhaps not. The provision in question was enacted in $1987 .{ }^{260}$ It is likely that Congress gave no thought to the possibility of unmarried cohabitants living in residences encumbered by mortgage debt in excess of the dollar limitation - which in 1987 dollars was quite significant. As discussed above, the statutory language is subject to two reasonable but contradictory interpretations. ${ }^{261}$ Most likely, this issue would be viewed by a court as one of the innumerable issues that were bound to occur in the implementation of the statute, the resolution of which Congress handed off to the I.R.S. ${ }^{262}$ Accordingly, Chevron deference should be accorded to the regulations.

With respect to the gift tax issue, the preceding arguments and counterarguments $^{263}$ do not consider whether the campaign finance statutes and their legislative history support or undermine the I.R.S.'s position - a consideration well beyond the scope of this work. It is possible that the intent of Congress with respect to this issue is indeed ambiguous; and, if so, that determination should be made without regard to whether or not the issue is important and central to campaign practices and, thus, would unlikely have been delegated to the I.R.S. Only after such a determination is made should the importance of the issue become relevant. If implicit delegation of authority to the I.R.S. exists, then Chevron deference should apply. If no such delegation took place, then

\footnotetext{
259. See S. REP. No. 93-1357, at 7502 (1974).

260. See I.R.C. § 163(h).

261. See supra notes $211-15$ and accompanying text.

262. On the other hand, it is not inconceivable that a court, because this issue implicated the treatment of same-sex couples and the role of tax incentives in effectuating federal housing policy, could believe that Congress would not have left its resolution to the agency. Chief Justice Roberts casually dismissed any analogy between section $36 \mathrm{~B}$ and the tax credit for first-time homebuyers on the ground that the latter credit is not central to federal housing policy. King v. Burwell, $135 \mathrm{~S}$. Ct. $2480,2495 \mathrm{n} .5$ (2015). It is unlikely that a court would consider the manner in which the mortgage interest deduction limitation is applied as central to federal housing policy.

263. See supra notes $254-59$ and accompanying text.
} 
the Chevron deference is inapplicable, the regulation struck down, and the issue sent back to Congress.

Whether an issue is important should not affect a court's efforts in ascertaining the intent of Congress. After all, one would and should, expect a court to make the same effort to ascertain Congress's intent in both situations described above. If Congress gave no thought to the matter, then whether the policy implications are important or whether the I.R.S. has the expertise to effectuate social, housing, and campaign finance policies should not be an excuse for a court to divine a nonexistent congressional intent. If Congress did not speak to the issue and did not delegate the authority for an agency to speak on the issue, then the regulation should be struck down and the issue returned to Congress. Otherwise, the court will have delegated to itself the authority that it denied an agency. Justice Stevens stated that:

When a challenge to an agency construction of a statutory provision,
fairly conceptualized, really centers on the wisdom of the agency's
policy, rather than whether it is a reasonable choice within a gap left
open by Congress, the challenge must fail. In such a case, federal
judges - who have no constituency-have a duty to respect legitimate
policy choices made by those who do. The responsibilities for
assessing the wisdom of such policy choices and resolving the struggle
between competing views of the public interest are not judicial ones:
"Our Constitution vests such responsibilities in the political
branches." 264

\section{B. Standing Revisited}

The Court's refusal to apply Chevron to the extraordinary cases in which the implication of congressional delegation of authority to an agency is unwarranted stands in contrast to the Court's standing jurisprudence. The requirement of standing is a mechanism that implements Article III's limitation of judicial power "to all Cases, in Law and Equity, arising under this Constitution, the Laws of the United States, and... to Controversies to which the United States shall be Party ...."265 In Asarco Inc. v. Kadish, the Court stated that "[a]lthough standing in its outer dimensions is a prudential concept to be shaped ... as a matter of sound judicial policy and subject to the control of

264. Chevron, U.S.A., Inc. v. Nat. Res. Def. Council, Inc., 467 U.S. 837, 866 (quoting Tenn. Valley Auth. v. Hill, 437 U.S. 153, 195 (1978)).

265. U.S. CONST. art. III, § 2, cl. 1. 
Congress, at its core it becomes a constitutional question . . ."266 Except in circumstances in which federal taxing and spending power allegedly violates the Establishment Clause, taxpayer challenges to federal tax decisions will not maintain if the taxpayer alleges no more than a harm that the taxpayer has in common with all taxpayers. ${ }^{267}$

Federal taxpayer standing jurisprudence had its genesis in the 1923 case of Frothingham v. Mellon. ${ }^{268}$ In that case, a taxpayer alleged that the Federal Maternity Act of 1921, by encroaching on areas that were traditionally the states' domain, violated the Tenth Amendment and that the federal expenditures under the statute increased her tax bill in violation of due process. ${ }^{269}$ The Court denied the taxpayer standing stating that the effect of the expenditures on her federal tax liability was "so remote, fluctuating and uncertain" and that her interest "in the moneys of the treasury" was "shared with millions of others." 270 According to the Court, a party can invoke federal judicial power upon a showing "not only that the statute is invalid, but that he has sustained ... some direct injury as the result of its enforcement, and not merely that he suffers in some indefinite way in common with people generally." ${ }^{271}$ In a relatively recent decision, DaimlerChrysler Corp. v. Cuno, the Court made clear that Frothingham applies with equal force to taxpayer challenges to state tax and spending provisions. ${ }^{272}$

The Court has been similarly unreceptive to suits brought by members of Congress that allege an injury to such members' lawmaking powers. In Raines $v$. Byrd, several members of Congress claimed that

\footnotetext{
266. 490 U.S. 605,613 (1989).

267. The Court asserted that the framers adopted the Establishment Clause because they feared that "the taxing and spending power would be used to favor one religion over another or to support religion in general." Flast v. Cohen, 392 U.S. 83, 103 (1968). Therefore, the Establishment Clause serves as a "specific constitutional limitation" on Congress's power to tax and spend under Article I, section 8. Id. at 104. The Flast exception has been limited to challenges to Congress's power to tax and spend. See, e.g., United States v. Richardson, 418 U.S. 166, 170 (1974).

268. See 262 U.S. 447 (1923).

269. See id. at $479-80$.

270. Id. at 487.

271. Id. at 488. Moreover, the Court, none too persuasively, distinguished this case from Crampton v. Zabriskie, which in 1879 held that a local taxpayer action may stand. 101 U.S. 601 (1879); Frothingham, 262 U.S. at 486-87. In the Court's opinion, local taxpayers' stake in the local treasury is direct and immediate, unlike federal taxpayers' interest in the federal treasury. See id.

272. 547 U.S. $332,344-45$ (2006). In that case, the plaintiffs alleged that property tax relief and a state tax credit granted to the DaimlerChrysler Corp., pursuant to a contract entered into between the corporation and the City of Toledo, violated the Commerce Clause. Id. at 337-39. After citing to various of its precedents, Chief Justice Roberts stated that " $[t]$ he foregoing rationale for rejecting federal taxpayer standing applies with undiminished force to state taxpayers." Id. at 345.
} 
the Line Item Veto Act unconstitutionally rendered their votes on appropriation bills less effective. ${ }^{273}$ Despite the fact that the statute expressly conferred standing to members of Congress, the Court held that such injury was "wholly abstract and widely dispersed" and thus not cognizable. ${ }^{274}$ The Court made clear that Article III barriers to standing cannot be removed by a congressional grant of standing. ${ }^{275}$ Justice Souter pointedly invoked the separation of powers rationale for the denial of standing to members of Congress for alleged institutional injuries. ${ }^{276}$ A congressperson's standing will require an allegation of personal injury as opposed to institutional injury. ${ }^{277}$

Legislators may have standing to challenge executive action in the absence of a particularized individual harm if they undertake the challenge in a representational capacity. In a recent federal district court case, a committee of the House of Representatives had standing to enforce a subpoena issued by the committee to a member of the executive branch. ${ }^{278}$ In INS v. Chadha, a federal statute permitting either house of Congress to overrule a decision by the Immigration and Naturalization Service to allow a deportable alien to remain in the United States was held unconstitutional upon challenge by the petitioner alien. ${ }^{279}$ The Ninth Circuit permitted Congress to intervene and defend the

273. 521 U.S. 811, 816 (1997).

274. Id. at 829. See also Line Item Veto Act, Pub L. No. 104-130, § 3(a), 110 Stat. 1200, 1211

(1996). The Act was subsequently declared unconstitutional in Clinton v. City of New York. 524 U.S. 417, 449 (1998).

275. Raines, 521 U.S. at 820 n.3.

276. Id. at 832-33 (Souter, J., concurring in the judgment).

277. In Powell v. McCormack, the standing of Representative Adam Clayton Powell, Jr. was based on the injury he alleged from the refusal of other members of Congress to seat him. 395 U.S. 486, 489 (1969). The D.C. Circuit, in Shays v. FEC, upheld the standing of two members of Congress to challenge the Federal Election Commission's interpretation of the certain provisions of the McCain-Feingold Act. 414 F.3d 76, 82-83 (D.C. Cir. 2005). The plaintiffs asserted that the Federal Election Commission regulations in question were impermissibly liberal and, as a consequence, they were injured because of the effect that such regulations would have on the behavior of their campaign opponents and donors. See id. at 83-85. Members of Congress challenged various provisions of the McCain-Feingold Act asserting not injuries to their status as members of Congress but injuries due to their candidacy for office. See McConnell v. FEC, 540 U.S. 93, 224-30 (2003), overruled by Citizens United v. FEC, 588 U.S. 310 (2010). The Court denied standing to the plaintiffs to challenge several of the provisions of the statute, but such denial was not predicated on the status of any of the plaintiffs as members of Congress. Id. Instead, the Court denied standing on the inability of the plaintiffs to show an injury in fact for certain provisions and the inability to show the requested relief would redress the alleged injuries for other provisions. Id.

278. Comm. on the Judiciary, U.S. House of Representatives v. Miers, 558 F. Supp. 2d 53, 55, 68 (D.D.C. 2008).

279. 462 U.S. 919, 928 (1983). 
constitutionality of the statute. ${ }^{280}$ In affirming this decision, the Court stated that "Congress is the proper party to defend the validity of a statute when an agency of government, as a defendant charged with enforcing the statute, agrees with plaintiffs that the statute is inapplicable or unconstitutional." 281 However, because the Court held that the petitioner maintained standing in the case, it was not necessary for Congress to maintain standing in its own right in order to intervene. ${ }^{282}$

United States $v$. Windsor, ${ }^{283}$ the case that struck down the Defense of Marriage Act (DOMA), raised standing issues similar to Chadha. The respondent challenged the constitutionality of DOMA after she was assessed an estate tax deficiency. ${ }^{284}$ The deficiency arose because the respondent, married under state law to a same-sex partner, was not deemed married for federal estate tax purposes due to the application of DOMA. $^{285}$ The Bipartisan Litigation Advisory Group (BLAG) of the House of Representatives petitioned to intervene to defend the statute as an interested party after being notified by the Attorney General that the Department of Justice would not defend the statute's constitutionality. ${ }^{286}$ Because the Court held that the petitioner and respondent maintained standing, it did not decide whether BLAG had standing in its own right. ${ }^{287}$ Justice Alito, however, believed that BLAG did have standing to defend the statute, and he would maintain the standing of a member of Congress to defend the constitutionality of any statute provided that the member has the institutional imprimatur to do so. ${ }^{288}$ "Accordingly, in the narrow category of cases in which a court strikes down an Act of

\footnotetext{
280. See id. at 939-40.

281. Id. at 940 (citing Cheng Fan Kwok v. INS, 392 U.S. 206, 210 n.9 (1968); United States v. Lovett, 328 U.S. 303, 305 (1946)).

282. See id. at 935-36, 939-40.

283. 133 S. Ct. 2675 (2013).

284. Id. at 2682 .

285. Id. at 2683. Property that passes to a surviving spouse is not subject to the federal estate tax. See I.R.C. $\$ 2056$ (2012). After Windsor, it was not unexpected that the Court would prohibit state marriage laws from discriminating on the basis of sexual orientation. On June 26, 2015, the Court held that the Fourteenth Amendment requires a state to license a marriage between two people of the same sex and to recognize a marriage between two people of the same sex when their marriage was lawfully licensed and performed by another state. See Obergefell v. Hodges, $135 \mathrm{~S}$. Ct. 2584, 2604-05, 2607-08 (2015).

286. Windsor, 133 S. Ct. at 2684. The Rules of the House of Representatives formally acknowledge and refer to the Bipartisan Legal Advisory Group, as such, in connection with its function of providing direction to the Office of the General Counsel. See Rules of the House of Representatives, 114th Cong., Rule II.8 (2015), http://clerk.house.gov/legislative/house-rules.pdf.

287. Windsor, 133 S. Ct. at 2686, 2688.

288. Id. at 2712 (Alito, J., dissenting).
} 
Congress and the Executive declines to defend the Act, Congress both has standing to defend the undefended statute and is a proper party to do so. $" 289$

In King $v$. Burwell, the I.R.S. interpreted the tax credit expansively. ${ }^{290}$ Section $36 \mathrm{~B}$ is not a typical credit provision because the availability of the credit has consequences beyond the reduction of a taxpayer's tax liability. Credit eligibility is a factor in determining insurance affordability and, therefore, could trigger the individual mandate for a taxpayer. ${ }^{291}$ Moreover, credit eligibility could also trigger the employer mandate. ${ }^{292}$ Consequently, standing is not an issue because, despite the seemingly taxpayer-favorable nature of the I.R.S. regulations, particularized harms could occur to certain taxpayers.

However, let us assume for the moment that section 36B did nothing more than reduce a taxpayer's tax liability and that the legislation clearly reflected the intent of Congress to limit tax credits to enrollees on State Exchanges. Despite the fact that the Court believed the tax credits were an integral part of the health insurance reform effort - an extraordinary case - no one could maintain standing to challenge the regulations. The fact that such a situation could be resolved through the political process does not distinguish it from the situation in King. If the dissent's view carried the day, then the political process could have been invoked to achieve the opposite result. If Congress did not delegate authority to an agency to act in "extraordinary" situations, then the invocation of the separation of powers rationale - the same rationale that denies the applicability of Chevron - should not depend on whether an agency's illegitimate exercise of power solely benefits taxpayers.

The Court's standing jurisprudence may be, in some respects, an

289. Id. at 2714. The Court has made clear that state legislators have standing to bring an action in defense of a statute if they are doing so in an official capacity. The Court held that because state law authorized the presiding legislative officers to represent the New Jersey legislature in litigation, the Speaker of the General Assembly and the President of the Senate had standing to defend state legislation. Karcher v. May, 484 U.S. 72, 81-82 (1987). The Court denied standing in this case because the authority to represent the legislature had passed to parties' successors in office. See id. at 76-77. A federal district court recently held that the House of Representatives did have standing to challenge the Obama Administration's use of unappropriated funds to implement portions of the Patient Protection and Affordable Care Act, but did not have standing to challenge delays in the statute's implementation. See supra note 39.

290. See supra notes 54-73.

291. This is precisely what occurred in King v. Burwell. 135 S. Ct. 2480 (2015). See supra note 56 and accompanying text.

292. See supra notes 34-36 and accompanying text. 
abdication of Marbury v. Madison. ${ }^{293}$ The "Take Care" Clause is not hortatory. It imposes a duty upon the President- "he shall take Care that the Laws be faithfully executed ...."294 The Court has seen fit to create exceptions to its traditional aversion to taxpayer standing. Under Flast v. Cohen, taxpayer standing is maintained for challenges to congressional spending and taxing decisions that allegedly violate the First Amendment's Establishment Clause. ${ }^{295}$ According to Flast, the Establishment Clause protects an interest important enough to justify an exception to the Court's traditional aversion to taxpayer standing. ${ }^{296}$ Flast can be taken as evidence that the Court's standing jurisprudence is rooted more in prudential concerns than Article III constitutional impediments.

Surely the assertion that an agency has not been delegated the power to act by Congress raises an issue of sufficient import to overcome the standing barriers. The Court, at a minimum, should grant a member of Congress standing to challenge agency action if the agency acted without express or implied authority. If an issue is of such significance-an extraordinary case - that it belies congressional delegation of authority to an agency to act as it did, then to deny anyone the ability to challenge agency action is fundamentally inconsistent with the separation of powers foundation for the Court's refusal to invoke Chevron for the resolution of important questions. Such an exception would apply only to "extraordinary" cases and, therefore, would raise few prudential concerns.

\section{CONCLUSION}

Whether one believes that the Court deserves praise or criticism for its holding in King v. Burwell is, I suspect, based on the result for which one hoped. This was not an easy case of statutory interpretation. I agree with the Court that an implied delegation of authority by Congress to the I.R.S. to resolve the issue of tax credit availability was unlikely. This case presented an issue central and critical to the policies underlying the legislation and was an issue so obvious that Congress surely intended some result. However, the Court's reasoning with respect to the

293. For a thoughtful critique of the Court's standing jurisprudence, see Richard A. Epstein, Standing and Spending-The Role of Legal and Equitable Principles, 4 CHAP. L. REV. 1 (2001).

294. U.S. Const., art. II, § 3 (emphasis added).

295. See supra note 267 and accompanying text.

296. Id. 
application of Chevron in the extraordinary case in which Congress retained for itself the resolution of an issue is troubling. Its reasoning appears to offer the courts an excuse to take for itself what Congress reserved for itself. 